\title{
Temporal biomass dynamics of an Arctic plankton bloom in response to increasing levels of atmospheric carbon dioxide
}

\author{
K. G. Schulz ${ }^{1}$, R. G. J. Bellerby ${ }^{2,3,4}$, C. P. D. Brussaard ${ }^{5}$, J. Büdenbender ${ }^{1}$, J. Czerny ${ }^{1}$, A. Engel $^{1}$, M. Fischer ${ }^{1}$, \\ S. Koch-Klavsen ${ }^{1}$, S. A. Krug ${ }^{1}$, S. Lischka ${ }^{1}$, A. Ludwig ${ }^{1}$, M. Meyerhöfer ${ }^{1}$, G. Nondal ${ }^{6}$, A. Silyakova ${ }^{2,3}$, A. Stuhr ${ }^{1}$, and \\ U. Riebesell ${ }^{1}$ \\ ${ }^{1}$ Helmholtz Centre for Ocean Research (GEOMAR), Düsternbrooker Weg 20, 24105 Kiel, Germany \\ ${ }^{2}$ Uni Bjerknes Centre, Allégaten 55, 5007 Bergen, Norway \\ ${ }^{3}$ Bjerknes Centre for Climate Research, Allégaten 55, 5007 Bergen, Norway \\ ${ }^{4}$ Geophysical Institute, University of Bergen, Allégaten 70, 5007, Norway \\ ${ }^{5}$ Royal Netherlands Institute for Sea Research (NIOZ), P.O. Box 59, 1790 AB Den Burg (Texel), The Netherlands \\ ${ }^{6}$ Norwegian Institute for Water Research (NIVA), Thormøhlensgaten 53D, 5006 Bergen, Norway
}

Correspondence to: K. G. Schulz (kschulz@geomar.de)

Received: 17 August 2012 - Published in Biogeosciences Discuss.: 14 September 2012

Revised: 10 December 2012 - Accepted: 11 December 2012 - Published: 11 January 2013

\begin{abstract}
Ocean acidification and carbonation, driven by anthropogenic emissions of carbon dioxide $\left(\mathrm{CO}_{2}\right)$, have been shown to affect a variety of marine organisms and are likely to change ecosystem functioning. High latitudes, especially the Arctic, will be the first to encounter profound changes in carbonate chemistry speciation at a large scale, namely the under-saturation of surface waters with respect to aragonite, a calcium carbonate polymorph produced by several organisms in this region. During a $\mathrm{CO}_{2}$ perturbation study in Kongsfjorden on the west coast of Spitsbergen (Norway), in the framework of the EU-funded project EPOCA, the temporal dynamics of a plankton bloom was followed in nine mesocosms, manipulated for $\mathrm{CO}_{2}$ levels ranging initially from about 185 to $1420 \mu \mathrm{atm}$. Dissolved inorganic nutrients were added halfway through the experiment. Autotrophic biomass, as identified by chlorophyll $a$ standing stocks ( $\mathrm{Chl} a$ ), peaked three times in all mesocosms. However, while absolute Chl $a$ concentrations were similar in all mesocosms during the first phase of the experiment, higher autotrophic biomass was measured as high in comparison to low $\mathrm{CO}_{2}$ during the second phase, right after dissolved inorganic nutrient addition. This trend then reversed in the third phase. There were several statistically significant $\mathrm{CO}_{2}$ effects on a variety of parameters measured in certain phases, such as nutrient utilization, standing stocks of particulate organic matter, and phytoplankton species composition. Interestingly, $\mathrm{CO}_{2}$ effects de-
\end{abstract}

veloped slowly but steadily, becoming more and more statistically significant with time. The observed $\mathrm{CO}_{2}$-related shifts in nutrient flow into different phytoplankton groups (mainly dinoflagellates, prasinophytes and haptophytes) could have consequences for future organic matter flow to higher trophic levels and export production, with consequences for ecosystem productivity and atmospheric $\mathrm{CO}_{2}$.

\section{Introduction}

Anthropogenic emissions of carbon dioxide $\left(\mathrm{CO}_{2}\right)$ affect the oceans directly by shifting carbonate chemistry speciation, and indirectly by warming with associated changes in light and nutrient availability, potentially impacting autotrophic growth and biogeochemical element cycling (e.g. Sarmiento et al., 2004; Riebesell et al., 2009; Marinov et al., 2010 and references therein). Shifts in carbonate chemistry speciation include decreases in $\mathrm{pH}$, carbonate ion concentrations and subsequently in carbonate saturation states (termed ocean acidification), and increases in bicarbonate and dissolved inorganic carbon concentrations (often referred to as ocean carbonation).

Ocean change is a global phenomenon, especially in surface waters. However, some regions are projected to be affected more, or more quickly, than others. High latitudes, 
with their cold sea surface temperatures have naturally low carbonate saturation states. The Arctic is projected to precede the Antarctic in being the first region to become undersaturated on a larger scale for one of the calcium carbonate polymorphs, aragonite, already in a few decades (Steinacher et al., 2009). However, regionally and seasonally, Arctic sea ice melt or biological activity on top of ongoing ocean acidification causes aragonite under-saturation already today (Bates et al., 2009; Yamamoto-Kawai et al., 2009). Also pH is projected to decrease more quickly, mainly due to melting ice and seawater freshening, but this can be considered of minor importance in comparison to the overall changes (Steinacher et al., 2009).

At carbonate saturation states below one, i.e. undersaturation, calcium carbonate will start to dissolve. Aragonite and calcite, two forms of calcium carbonate, are produced by a variety of marine organisms such as foraminifera, coccolithophores, pteropods, corals, molluscs, echinoderms or coralline algae. Most of these have been shown to be impacted to a certain degree by ocean acidification in various laboratory studies, already at calcium carbonate oversaturated levels (see Kroeker et al., 2010 for a meta-analysis).

Concerning marine phytoplankton, it is rather changing $\mathrm{pH}$ and/or $\mathrm{CO}_{2}$ than carbonate saturation state that influences individual performance, probably connected to different modes and sensitivities of carbon concentrating mechanisms (see e.g. Giordano et al., 2005 or Reinfelder, 2010 for reviews). While physiological studies on the effects of changes in carbonate chemistry on single species of marine phytoplankton are countless, only a few studies focus on potential changes in entire phytoplankton community assemblages (see e.g. Tortell et al., 2002, 2008; Kim et al., 2006; Hare et al., 2007; Schulz et al., 2008; Feng et al., 2009; Biswas et al., 2011). However, there is no coherent picture, eventually related to differences in experimental design (batch or semi-continuous bottle cultures, or mesocosms), condition (nutrient replete or deplete, and incubation time) and analysis (relative or absolute abundances, and statistics).

Mesocosm experiments, comprising natural plankton communities and several trophic levels, are an ideal platform to assess potential effects of changing carbonate chemistry as they allow for species interaction and competition in a quasi-natural environment (Riebesell et al., 2008, 2012). Here we report on a mesocosm $\mathrm{CO}_{2}$ perturbation study in Kongsfjorden on the west coast of Spitsbergen (Norway) in the Arctic. Unfortunately, one of the foci, the response of Limacina helicina, an important food-web component and marine calcium carbonate producing pteropod, to ongoing ocean acidification, had to be dropped due to technical difficulties (see Sect. 2.1 for details). Nevertheless, temporal biomass and phytoplankton assemblage dynamics were followed for about one month.

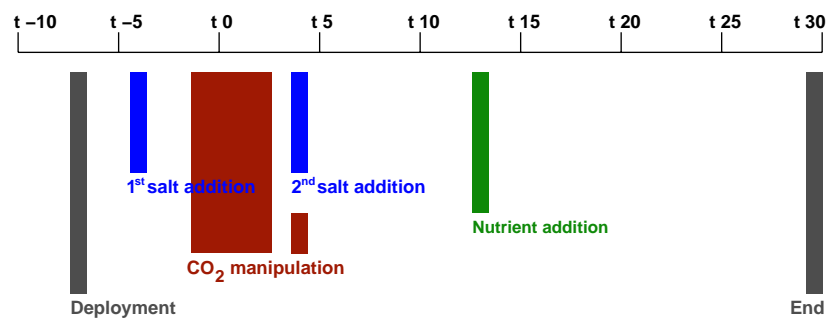

Fig. 1. Timeline of major experimental manipulations. Mesocosm deployment was on 31 May, day $t-7$. The experiment ended on 7 July on day $t 30$. See Sect. 2 for details.

\section{Methods}

\subsection{Mesocosm setup}

On 31 May 2010 (day $t-7$ ), nine mesocosms were deployed at $78^{\circ} 56.2^{\prime} \mathrm{N}, 11^{\circ} 53,6^{\prime} \mathrm{E}$ in Kongsfjorden on the west coast of Spitsbergen, the largest island of the archipelago of Svalbard, Norway (for a summary of important dates and manipulations, see Fig. 1). The floating structures of the Kiel Off-Shore Mesocosms for future Ocean Simulations, KOSMOS (Fig. 2), were moored in clusters of three, and filling of the attached cylindrical bags $(0.5-1 \mathrm{~mm}$ thick, $17 \mathrm{~m}$ long and $2 \mathrm{~m}$ in diameter thermoplastic polyurethane) started on the morning of the following day. For that purpose, the opened bottom plates of the bags were lowered carefully to $15 \mathrm{~m}$ depth, thereby slowly filling the mesocosms with natural fjord water. A $3 \mathrm{~mm}$ mesh-sized screen attached to the bottom plates excluded larger organisms such as pteropods, which, due to their relatively patchy distribution in the water column, would not have been represented at similar abundances in all mesocosms. Furthermore, to minimize potential discrepancies in phytoplankton community composition between bags, caused by differences in timing of filling and small-scale spatial separation of the mesocosms, the upper parts of the bags were pulled down about $1.5 \mathrm{~m}$ beneath the water surface. Again, a $3 \mathrm{~mm}$ mesh-sized screen attached to the upper part of the bags kept larger organisms outside the mesocosms, which, now open to the fjord at both sides, integrated passing fjord water for about two days. Similarity between the seawater enclosed in each mesocosm was ensured by subsequent CTD (conductivity, temperature, and depth) casts, comparing vertical profiles of salinity, temperature, chlorophyll $a(\mathrm{Chl} a)$, turbidity, $\mathrm{pH}$ and oxygen concentrations. On the evening of 2 June the mesocosms were closed at the bottom by divers, while the upper parts of the bags were simultaneously retrieved and attached to the floating structures in about $2 \mathrm{~m}$ above the water surface. On top of the floating structures, about $0.5 \mathrm{~m}$ above the upper rim of the mesocosm bags, dome-shaped hoods minimized freshwater and dirt input from above. The closing of the bottom plates also unfolded a conical sediment trap in each mesocosm, 


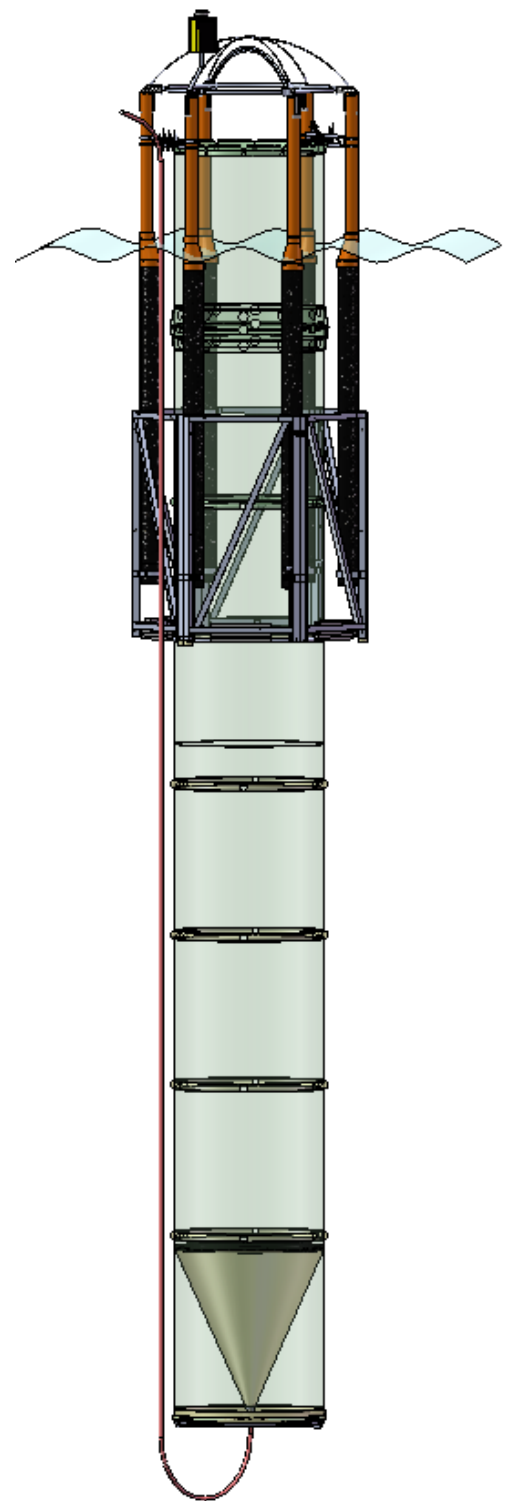

Fig. 2. Schematic drawing of a KOSMOS mesocosm deployed in Kongsfjorden, with its characteristic dead space below the sediment trap, shown in dark grey, at the bottom.

about $2 \mathrm{~m}$ high and $2 \mathrm{~m}$ in diameter, thereby covering the entire bag (see also Riebesell et al., 2012).

Pteropods are important components of Arctic plankton communities. However, due to their patchy distribution they have been excluded during filling of the bags, avoiding otherwise uneven abundances between mesocosms. Adult pteropods of the species Limacina helicina were, therefore, hand-picked at different locations within Kongsfjorden. It took several attempts and three collection days to find sufficient numbers, and 100, 20 and 70 individuals were added to each mesocosm on days $t 4,5$ and 6 , respectively. Unfortunately, they disappeared from the mesocosm water column relatively quickly. Most of them got trapped in the dead space below the sediment traps (Fig. 2) and died, potentially related to their natural floating/sinking behaviour.

\subsection{Salt addition}

Certain manipulations, such as dissolved inorganic nutrient addition, require knowledge of the exact seawater volume enclosed in each mesocosm bag. Otherwise, differences in volume would be directly reflected in nutrient concentration differences between mesocosms. The volume was estimated by adding known amounts ( $50 \mathrm{~kg}$ per mesocosm) of sodium chloride $(\mathrm{NaCl})$ enriched seawater $(250 \mathrm{~g} \mathrm{NaCl}$ per kg of seawater) to each mesocosm with subsequent determination of changes in salinity ( $\sim 0.2$ units). For that purpose, a dispersal device was lowered down to the opening of the conical sediment trap in $13 \mathrm{~m}$ depth and pulled up again to the surface several times. Pumping of the $\mathrm{NaCl}$-enriched seawater through the dispersal device evenly distributed the salt addition in the mesocosm water column. Vertical salinity profiles taken before and after were then used to determine the increase in salinity and hence estimate the seawater volume in each mesocosm bag. Briefly, the vertically integrated change in salinity in the mesocosms was compared to a calibration curve, describing the relation of measured change in salinity upon the addition of varying amounts of $\mathrm{NaCl}$-enriched seawater to a known amount of mesocosm water. Mesocosm volume was found to range between 43.9 and $47.6 \mathrm{~m}^{3}$. With the hand-operated memory probe CTD 60M from Sea and Sun Technology (see Sect. 2.5 for details), the typical uncertainty in volume estimate was found to be less than $1 \%$. For further details on practical aspects and theoretical considerations of the salt addition, see Czerny et al. (2012b).

$\mathrm{NaCl}$-enriched seawater was added to each mesocosm twice, on day $t-4$ and $t 4$ (Fig. 1). A second addition was found necessary as the volume estimate from the first was impaired by considerable uncertainties in initial salinity profiles. These uncertainties were caused by relatively slow (on the order of days) exchange and equilibration rates of the mesocosm water with that of the dead space below the sediment trap (Fig. 2), which initially had a slightly higher salinity in comparison to average mesocosm water.

\subsection{Carbon dioxide addition}

$1.5 \mathrm{~m}^{3}$ of $50 \mu \mathrm{m}$ filtered seawater taken from the fjord were aerated with pure $\mathrm{CO}_{2}(99.995 \%)$ for a minimum of $24 \mathrm{~h}$. This $\mathrm{CO}_{2}$-enriched seawater was used to increase dissolved inorganic carbon (DIC) and manipulate the carbonate system in seven out of nine mesocosms while the remaining two served as control. The addition of $\mathrm{CO}_{2}$-enriched seawater increased DIC while leaving total alkalinity (TA) constant, perfectly mimicking ongoing ocean acidification (Schulz et al., 2009; Gattuso et al., 2010). For details on carbonate chemistry measurements and calculations, see Bellerby et al. (2012). 

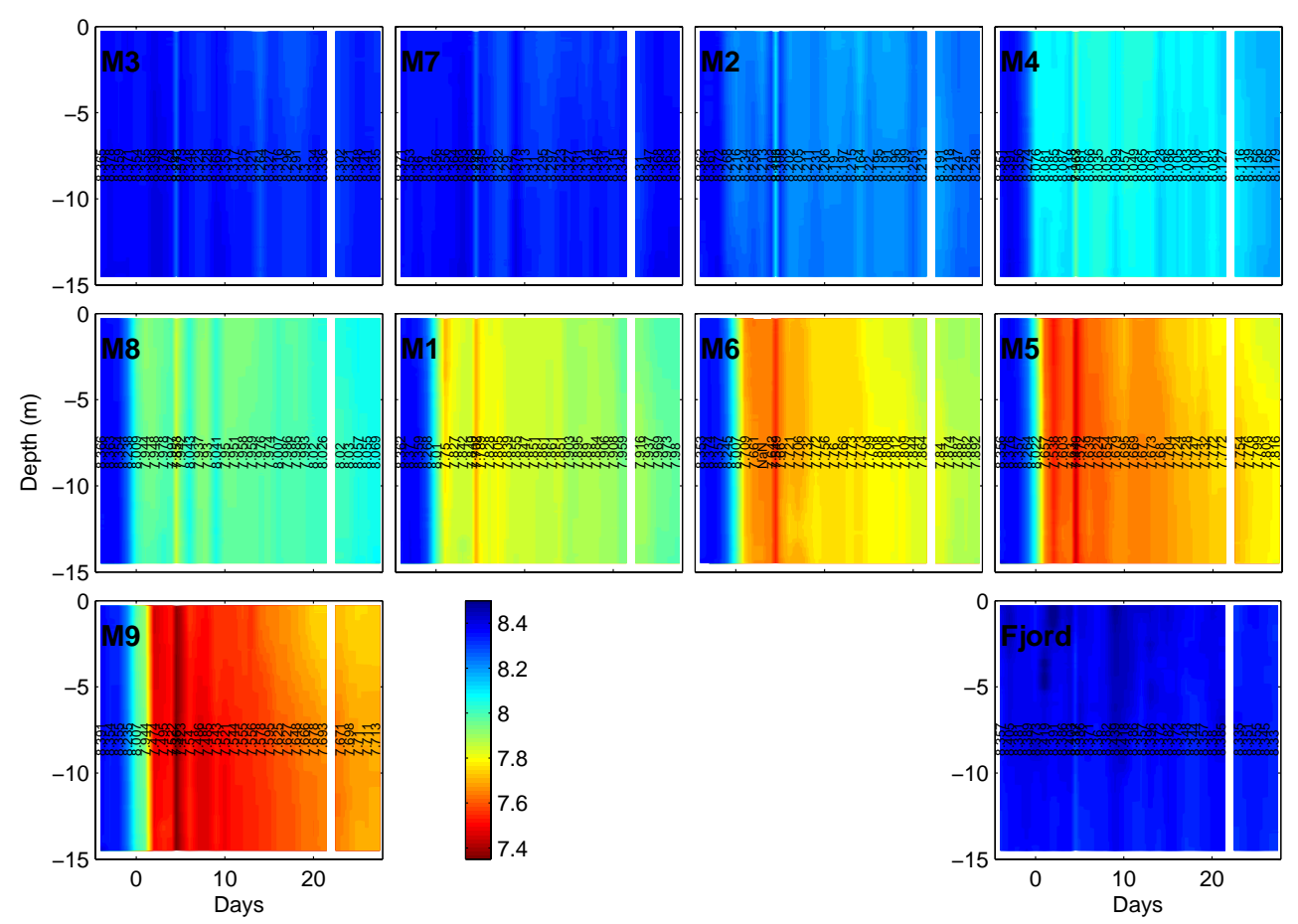

Fig. 3. Temporal pH dynamics in each mesocosm and the fjord. Vertical profiles were taken daily by means of a hand-operated CTD. Recorded $\mathrm{pH}$ values were corrected by calculated $\mathrm{pH}$ from measured dissolved inorganic carbon and total alkalinity and are reported on the total scale. Black numbers denote daily depth-averaged (0.3-12 m) mean pH values. See Sect. 2 for further details.

The addition was gradual between day $t-1$ and day $t 4$ (Fig. 1) by pumping varying amounts of the $\mathrm{CO}_{2}$-enriched seawater (Table 1) through a dispersal device, which was lowered to about $13 \mathrm{~m}$ depth in the mesocosms and pulled up again several times, resulting in an even distribution throughout the water column (Fig. 3). This way, gradients of increasing partial pressures of carbon dioxide $\left(p \mathrm{CO}_{2}\right)$ and decreasing $\mathrm{pH}$ were created in the nine mesocosms, ranging after equilibration with the water in the dead space between 185$1420 \mu \mathrm{atm}$ and 8.32-7.51, respectively (Table 1). Although $p \mathrm{CO}_{2}$ levels of $185 \mu \mathrm{atm}$ in the two control mesocosms were significantly lower than the atmospheric counterpart, they are nevertheless representative for post-bloom conditions at this time of the year (also compare values for the fjord in Table 1). The $\mathrm{CO}_{2}$ addition was such that five out of seven mesocosms would be within levels projected until the end of this century. The two highest treatments were chosen to keep them under-saturated with respect to aragonite until the end of the experiment, despite significant carbonate chemistry speciation changes related to biological activity and air/sea gas exchange of $\mathrm{CO}_{2}$.

\subsection{Nutrient addition}

The dissolved inorganic nutrient addition in the morning of day $t 13$ (Fig. 1) was meant to simulate the upwelling of deeper, nutrient-rich waters to a nutrient-depleted surface.
The addition was chosen to increase dissolved inorganic nutrients to reasonable concentrations in comparison to deeper waters. At $30 \mathrm{~m}$ depth phosphate concentrations were measured at about $0.6 \mu \mathrm{mol} \mathrm{L}{ }^{-1}$. Thus, the addition was targeted to increase phosphate by 0.31 (about half of deep water levels), nitrate by 5.0 (according to Redfield proportions) and silicate by $2.5 \mu \mathrm{mol} \mathrm{L}^{-1}$ (half of nitrate addition).

A stock solution was prepared in $50 \mu \mathrm{m}$ filtered fjord water, containing $10 \mathrm{mM}$ nitrate, $0.62 \mathrm{mM}$ phosphate and $5 \mathrm{mM}$ silicate. For that, the respective sodium salts $\mathrm{NaNO}_{3}$, $\mathrm{NaH}_{2} \mathrm{PO}_{4} \times 2 \mathrm{H}_{2} \mathrm{O}$ and $\mathrm{Na}_{2} \mathrm{SiO}_{3} \times 5 \mathrm{H}_{2} \mathrm{O}$ were dissolved in deionized water $(18.2 \mathrm{M} \Omega$ ) and added to the filtered seawater. Depending on mesocosm volume, $21.95-23.78 \mathrm{~kg}$ of this solution were then pumped into each mesocosm, employing the same technique and dispersal device as for the $\mathrm{CO}_{2}$ - or $\mathrm{NaCl}$-enriched seawater additions (see above). The nutrient addition was immediately followed by depth-integrated water sampling for nutrient analyses. For the future it is recommended to prepare the nutrient stock solution in deionized water as silicate at such relatively high concentrations was found to form precipitates in seawater, potentially in the form of sodium complexes. Although these complexes slowly dissolve again when diluted in seawater, they interfere with biogenic silica measurements (see Sect. 3.5 for details). 
Table 1. Amounts of $\mathrm{CO}_{2}$-enriched seawater added to the mesocosms between day $t-1$ and day $t 4$. Mesocosms that received no $\mathrm{CO}_{2}$ addition got $25 \mathrm{~L}$ of $50 \mu \mathrm{m}$ filtered natural seawater instead. Resulting $p \mathrm{CO}_{2}$ ( $\mu$ atm) and $\mathrm{pH}$ (on the total scale) after equilibration with the dead space are shown as a mean of day $t 8$ and $t 9$ values. For comparison initial (day $t-3$ ) values for $p \mathrm{CO}_{2}$ and $\mathrm{pH}$ of the fjord are also shown. Symbols and colour code denote those used in Figs. 6, 7, 8, 9, 10 and 11.

\begin{tabular}{lcccccccccc}
\hline & Fjord & M3 & M7 & M2 & M4 & M8 & M1 & M6 & M5 & M9 \\
\hline$t-1$ & & & & $50 \mathrm{~L}$ & $50 \mathrm{~L}$ & $50 \mathrm{~L}$ & $50 \mathrm{~L}$ & $50 \mathrm{~L}$ & $50 \mathrm{~L}$ & $50 \mathrm{~L}$ \\
$t 0$ & & & & & $25 \mathrm{~L}$ & $75 \mathrm{~L}$ & $75 \mathrm{~L}$ & $75 \mathrm{~L}$ & $75 \mathrm{~L}$ & $75 \mathrm{~L}$ \\
$t 1$ & & & & & & $25 \mathrm{~L}$ & $75 \mathrm{~L}$ & $75 \mathrm{~L}$ & $100 \mathrm{~L}$ & $100 \mathrm{~L}$ \\
$t 2$ & & & & $20 \mathrm{~L}$ & $20 \mathrm{~L}$ & & & $30 \mathrm{~L}$ & $40 \mathrm{~L}$ & $75 \mathrm{~L}$ \\
$t 4$ & & & & & & $5 \mathrm{~L}$ & $8 \mathrm{~L}$ & & $12 \mathrm{~L}$ & $20 \mathrm{~L}$ \\
\hline$\sum$ & & & & $70 \mathrm{~L}$ & $95 \mathrm{~L}$ & $155 \mathrm{~L}$ & $208 \mathrm{~L}$ & $230 \mathrm{~L}$ & $277 \mathrm{~L}$ & $320 \mathrm{~L}$ \\
\hline$p \mathrm{CO}_{2}$ & 170 & 185 & 185 & 270 & 375 & 480 & 685 & 820 & 1050 & 1420 \\
$\mathrm{pH}$ & 8.35 & 8.32 & 8.31 & 8.18 & 8.05 & 7.96 & 7.81 & 7.74 & 7.64 & 7.51 \\
& -- & -- & - & - & - & - & - & - & - & - \\
\hline
\end{tabular}

\subsection{Sampling procedures, CTD operation and light measurements}

If not stated otherwise, depth-integrated (0-12 m) samples were taken from each mesocosm and the fjord with an integrating water sampler, IWS (HYDRO-BIOS), between 09:00 and 11:00 LT from boats. Except for gas samples, which were directly filled from the sampler into sampling bottles on board, water samples were brought back to shore, stored at in situ water temperature in the dark and, depending on measurement parameter, usually processed further within the following hour.

CTD casts were taken daily (except day $t 22$ ) in each mesocosm and the fjord between 14:00 and 16:00 with a memory probe (CTD60M, Sea and Sun Technology). The CTD was equipped with a conductivity cell, turbidity meter, fluorometer for chlorophyll $a$, and temperature, $\mathrm{pH}$, dissolved oxygen and light sensors. For details on the sensors, respective accuracy and precision, and corrections applied, see Schulz and Riebesell (2012). Measured profiles, recorded with five data points per second and taken at $0.2-0.3 \mathrm{~m} \mathrm{~s}^{-1}$, were scaled to a uniform depth resolution of $2 \mathrm{~cm}$ by linear interpolation.

Photosynthetic active radiation (PAR) was measured with two LICOR quantum sensors (LI-192) mounted onshore on top of a $1.5 \mathrm{~m}$ pole and on the roof of the French research station, Charles Rabot, at one measurement per second. In seawater PAR profiles were collected by means of a CTD mounted LICOR spherical quantum sensor (LI-193).

\subsection{Analyses}

For particulate organic carbon and nitrogen (POC, PON), and total particulate carbon and nitrogen (TPC, TPN) analyses, $400-500 \mathrm{~mL}$ of sample water were filtered $(200 \mathrm{mbar})$ onto pre-combusted $\left(450^{\circ} \mathrm{C}\right.$ for $\left.5 \mathrm{~h}\right) \mathrm{GF} / \mathrm{F}$ filters, immediately stored frozen at $-20^{\circ} \mathrm{C}$. Prior to analyses filters were dried at $60^{\circ} \mathrm{C}$ and subsequently measured on a EuroVector elemental analyser according to Sharp (1974). POC filters were treated with fuming $\mathrm{HCl}$ in a desiccator for $2 \mathrm{~h}$ before drying and analysis. As there were no calcifying plankton found in microscopic counts, a mean of POC and TPC, and PON and TPN was calculated for each day and mesocosm.

For particulate organic phosphorus (POP), $400-500 \mathrm{~mL}$ of sample water were filtered onto pre-combusted $\left(450{ }^{\circ} \mathrm{C}\right.$ for $5 \mathrm{~h}$ ) GF/F filters. POP was then oxidized to orthophosphate by heating the filters in $40 \mathrm{~mL}$ of deionized water $(18.2 \mathrm{M} \Omega$ ) with Oxisolv (MERCK) in a pressure cooker and determined colorimetrically on a Hitachi U2000 spectrophotometer (Hansen and Koroleff, 1999; Holmes et al., 1999).

For biogenic silica (BSi) $250-450 \mathrm{~mL}$ of sample water were filtered onto cellulose acetate filters. Alkaline, borate buffered persulphate oxidation, in a pressure cooker was applied to transform biogenic BSi into silicate, which was subsequently determined spectrophotometrically (see Hansen and Koroleff, 1999 for details).

Determination of dissolved organic nitrogen (DON) and phosphorus (DOP) was on $\mathrm{GF} / \mathrm{F}$ (pre-combusted at $450^{\circ} \mathrm{C}$ for $5 \mathrm{~h}$ ) filtered sample water, which was heated together with Oxisolv (MERCK) in a pressure cooker. Oxidized organic nitrogen and phosphorus were measured spectrophotometrically as nitrate (nitrite) and phosphate, respectively, on a Hitachi V2000 (Hansen and Koroleff, 1999; Holmes et al., 1999). DON and DOP were calculated from a simple mass-balance taking dissolved inorganic nutrient concentrations into account.

Dissolved organic carbon (DOC) was determined on GF/F (pre-combusted at $450{ }^{\circ} \mathrm{C}$ for $5 \mathrm{~h}$ ) filtered sample water by high temperature catalytic oxidation (HTCO) on a SHIMADZU TOC-VCS. For details see Engel et al. (2012).

For chlorophyll $a(\mathrm{Chl} a$ ) analysis, $250-500 \mathrm{~mL}$ of sample water were filtered onto GF/F filters, immediately stored frozen for at least $24 \mathrm{~h}$. Filters were then homogenized in $90 \%$ acetone with glass beads ( 2 and $4 \mathrm{~mm}$ ) in a cell mill. After centrifugation at $800 \times \mathrm{g}$, Chl $a$ concentrations were 
determined in the supernatant on a fluorometer (TURNER, 10-AU) according to Welschmeyer (1994).

Preparations for pigment analyses were like for Chl $a$, except that they were solved in $100 \%$ acetone (HPLC grade), together with canthaxanthin as an internal standard to account for potential losses during sample handling. Pigment analyses were by high performance liquid chromatography (WATERS HPLC with a Varian Microsorb-MV 100-3 C8 column) according to Barlow et al. (1997). Phytoplankton community composition was calculated with the CHEMTAX algorithm (Mackey et al., 1996), by converting the concentrations of marker pigments to $\mathrm{Chl} a$ equivalents with suitable pigment to $\mathrm{Chl} a$ ratios (for details see Supplement).

Dissolved inorganic nutrients nitrate $\left(\mathrm{NO}_{3}^{-}\right)$, nitrite $\left(\mathrm{NO}_{2}^{-}\right)$, ammonium $\left(\mathrm{NH}_{4}^{+}\right)$, phosphate $\left(\mathrm{PO}_{4}^{3-}\right)$ and silicate $\left(\mathrm{H}_{4} \mathrm{SiO}_{4}\right)$ in the sample water were determined on a segmented flow analyser (SEAL QuAAtro) equipped with an autosampler. General methods described in Hansen and Koroleff (1999) were modified for nitrate (imidazole instead of an ammonium chloride buffer) and phosphate determinations, which followed Kerouel and Aminot (1997). Sodium dodecyl sulfate or Triton X-100 was used to lower surface tension and facilitate segmented flow analysis.

Counts of phytoplankton cells were on concentrated $(25 \mathrm{~mL})$ sample water, fixed with alkaline Lugol's iodine (1\% final concentration) in Utermöhl chambers with an inverted microscope (ZEISS Axiovert 100). At 200 times magnification, cells larger than $12 \mu \mathrm{m}$ were counted on half of the chamber area, while smaller ones were counted at 400 times magnification on two radial strips. Plankton were identified with the help of Tomas (1997); Hoppenrath et al. (2009); Kraberg et al. (2010) and von Quillfeldt (1996). Biovolumes of counted plankton cells were calculated according to Olenina et al. (2006) and converted to cellular organic carbon quotas by the equations of Menden-Deuer and Lessard (2000).

\subsection{Statistics}

In this study it was decided to establish a $\mathrm{CO}_{2}$ gradient rather than to replicate certain levels, mainly for two reasons. With nine mesocosms, and the relatively low amount of possible replicates, the statistical power of regression analyses in a treatment gradient in comparison to replicated ANOVA analyses is the same, if not superior (Cottingham et al., 2005). Furthermore, a gradient approach is less vulnerable to the potential loss of one or two mesocosm units. There are more advantages, all summarized nicely in Havenhand et al. (2010).

\subsubsection{Linear regression analyses}

Analyses for potentially statistically significant correlations of various measurement parameters with seawater partial pressure of carbon dioxide $\left(p \mathrm{CO}_{2}\right)$ in each of the experimen- tal phases (see below) were done by plotting the mean of the measurement parameter to be tested against the respective mean $p \mathrm{CO}_{2}$ of each mesocosm during a certain phase. Linear regressions were analysed with an F-test (see Table 2 for details)

\subsubsection{Multivariate community analyses}

First- and second-stage analyses were applied to three sets of data, i.e. the organics (POC, PON, POP, DON and DOP), the CHEMTAX together with Chl $a$, and the phytoplankton carbon biomass dataset, to identify anomalous time trajectory profiles of the nine mesocosms resulting from conventional first-stage resemblance matrices (Clarke et al., 2006). When the time trajectories in the first-stage analysis of the treated mesocosms increasingly separate with increasing $\mathrm{CO}_{2}$ and time from the control mesocosms, still plotting closely together, a $\mathrm{CO}_{2}$ effect becomes visible. This can be identified in the second-stage analysis where the treated mesocosms should, depending on their $\mathrm{CO}_{2}$ level, plot increasingly apart from the control mesocosms. To evaluate whether the time trajectories show any significant, continuous pattern of change with increasing $\mathrm{CO}_{2}$ level, a model severity matrix was created with a numeric factor for each mesocosm ( 0 for both controls and ascending from 1 to 7 , in the order of $\mathrm{CO}_{2}$ level, for the treated mesocosms). A subsequent RELATE test was run, comparing this model severity and second-stage matrix (Clarke and Gorley, 2006).

For the analyses, the organics dataset was $\log (x+1)$ transformed to remove some obvious skewness. The phytoplankton carbon biomass dataset was square root transformed prior to creating a resemblance matrix based on Bray-Curtis similarity (Clarke and Warwick, 2001). Additionally, the organics and the CHEMTAX + Chl $a$ datasets were normalized prior to creating a resemblance matrix based on Euclidean distance. Furthermore, it was necessary to exclude measuring days with incomplete data of certain parameters. Thus different numbers of days were included in the analyses of the three datasets.

\section{Results}

\subsection{Changes in light, salinity, temperature and oxygen concentrations}

With the exception of a few days, measured incident photosynthetic active radiation (PAR) at ground level in air during polar night was not lower than $150 \mu \mathrm{mol} \mathrm{m}^{-2} \mathrm{~s}^{-1}$. During polar day, maximum PAR levels were typically well above 700 and up to more than $1500 \mu \mathrm{mol} \mathrm{m}^{-2} \mathrm{~s}^{-1}$ (Fig. 4). Vertical light profiles and calculated light attenuation coefficients, $k d$ (derived by fitting normalized light profiles to the exponential equation $\mathrm{f}(x)=\exp ^{(-k d x)}$ ), ranging typically between 0.3 and 0.4 , showed little differences between mesocosms and the fjord. Depending on bloom situation, $2-15 \%$ and 
Table 2. $F, p$ and adjusted $R^{2}$ values of F-tests on linear regressions of all measurement parameters presented in Figs. 6, 7, 8, 9, 10 and 11 in each mesocosm and respective $p \mathrm{CO}_{2}$ during the three experimental phases. Statistically significant correlations are marked in bold for positive and italic for negative $p \mathrm{CO}_{2}$ correlations, respectively. It is noted that at a significance level of 0.05 one would expect 5 out of 100 regressions where the true null hypothesis that there is no causal relationship with $\mathrm{CO}_{2}$ is rejected, i.e. a $\mathrm{CO}_{2}$ dependance is postulated where there is none. Here 43 out of 111 regressions were found to be statistically significant related to $\mathrm{CO}_{2}$.

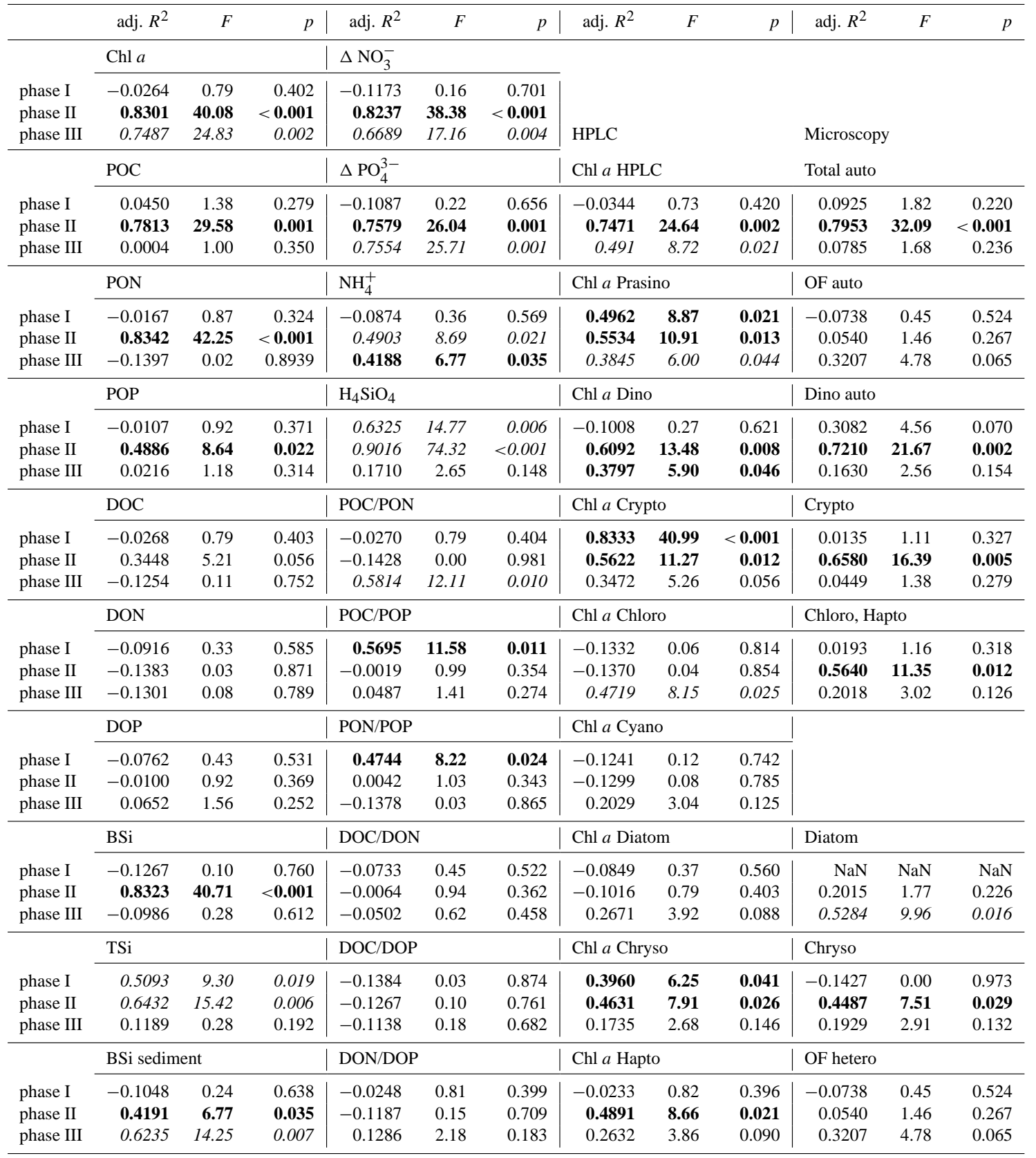

$20-30 \%$ of PAR was measured at $14.0 \mathrm{~m}$ and $3.7 \mathrm{~m}$ depth, respectively in comparison to the surface layer between 0.1 to $0.2 \mathrm{~m}$. Also absolute PAR levels must have been similar between mesocosms and fjord. On day $t 27 k d$ was about 0.37 , meaning that PAR at $3.7 \mathrm{~m}$ should be one-forth of incident light. And indeed, during a continuous light measurement for $40 \mathrm{~h}$ on the following days, four to six times less PAR was measured at $3.7 \mathrm{~m}$ depth in comparison to direct measurements at air (data not shown). The observed variability was probably connected to cloud cover and solar elevation angle. Thus, energy input into the water column of the fjord and the mesocosms were quite similar, and shading by the bags and the dome-shaped hoods were smaller than one might have expected. 


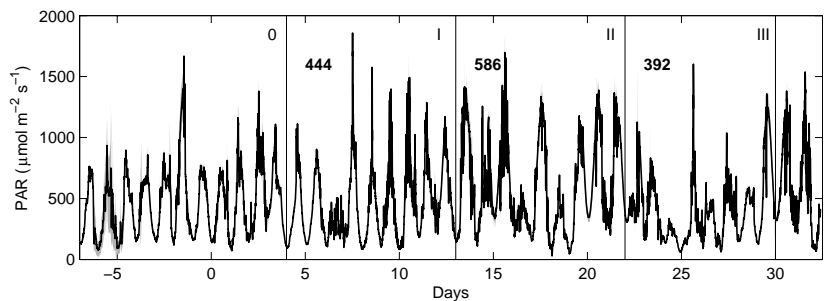

Fig. 4. Changes in photosynthetic active radiation (PAR) at ground level with time as measured by two LICOR sensors. The black line denotes the mean of both measurements while the grey shaded area illustrates the variability between them. Numbers denote average PAR levels during a certain phase, indicated by Roman numbers.

In the fjord, depth-averaged (0.3-12 m) salinity varied between 32.94 and 34.03 , with down to 29.59 at the surface and up to 34.29 at depth (Fig. 5a). In the mesocosms salinity was relatively stable, apart from the two salt additions on day $t-4$ and $t 4$, and steadily increased by about 0.002 units per day (Fig. 5b), translating into a concentration change of all constituents of about $2 \%$ within the experimental period of about 30 days. As there was no significant precipitation, this phenomenon was driven by evaporation.

Temperatures in the mesocosms closely followed those in the fjord and started at about $2{ }^{\circ} \mathrm{C}$, evenly distributed throughout the water column. Then water masses slowly warmed, especially in the upper 5 to $10 \mathrm{~m}$, reaching depthaveraged $(0.3-12 \mathrm{~m})$ values of up to $5.5^{\circ} \mathrm{C}$ towards the end of the experiment (Fig. 5c).

Initial oxygen concentrations (depth-averaged) in the fjord and mesocosms were about $450 \mu \mathrm{mol} \mathrm{kg}{ }^{-1}$. Considering an oxygen solubility of 310 to $340 \mu \mathrm{mol} \mathrm{kg}{ }^{-1}$ at 2 to $5^{\circ} \mathrm{C}$ at given salinities, waters were highly over-saturated. However, within a period of about 10 days, oxygen in the mesocosms decreased to saturation levels, probably driven by air/sea gas exchange. While concentrations remained close to these levels in the upper meters of the mesocosms, depth averaged (0.3-12 m) they steadily increased towards the end of the experiment by about $30 \mu \mathrm{mol} \mathrm{kg} \mathrm{kg}^{-1}$ (Fig. $5 \mathrm{~d}$ ).

\subsection{Changes in pH}

Initial $\mathrm{pH}$ levels in the fjord and mesocosms were relatively homogeneously distributed with depth at about 8.36 (reported on the total scale) as measured with a handoperated CTD (Fig. 3). Additions of varying amounts of $\mathrm{CO}_{2}$-enriched seawater (Table 1) to seven out of the nine mesocosms between day $t-1$ and day $t 4$ decreased depthaveraged $(0.3-12 \mathrm{~m}) \mathrm{pH}$ to about $8.18,8.05,7.96,7.81,7.74$, 7.64 and 7.51 in mesocosms M2, M4, M8, M1, M6, M5 and M9, respectively until days $t 8-9$. Note that the slight increase in $\mathrm{pH}$ measured on the days right after the last addition was caused by water exchange with non-treated water masses in the dead space below the sediment traps. While $\mathrm{pH}$ was rela-
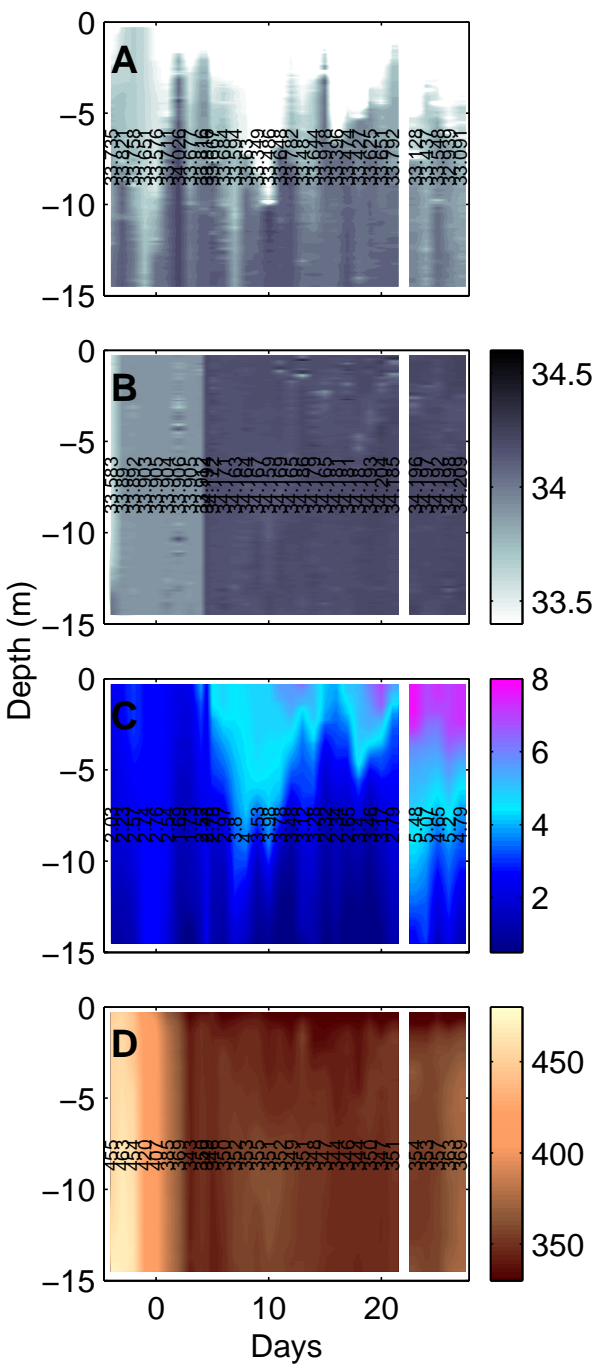

Fig. 5. Measured vertical distribution and change with time of salinity in the fjord (A) and mesocosm M1 (B), together with those of temperature (C) and oxygen concentration (D), reported in degrees celsius and $\mu \mathrm{mol} \mathrm{kg}-1$, respectively. Note that both vertical and temporal changes in salinity, temperature and oxygen were virtually identical between mesocosms. Vertical numbers denote depthaveraged $(0.3-12 \mathrm{~m})$ means of the respective parameter for each day.

tively stable throughout the experiment in the control mesocosms M3 and M7, pH increased in the other mesocosms, mostly driven by an interplay of air/sea gas exchange and biological consumption and production of $\mathrm{CO}_{2}$ (for details see Silyakova et al., 2012). Vertical pH distribution in the water column was relatively homogeneous throughout the experiment, with only slightly higher levels at the surface in the mesocosms with higher $\mathrm{CO}_{2}$ (Fig. 3). In the fjord, $\mathrm{pH}$ levels were relatively constant with time, as in the two control mesocosms. 


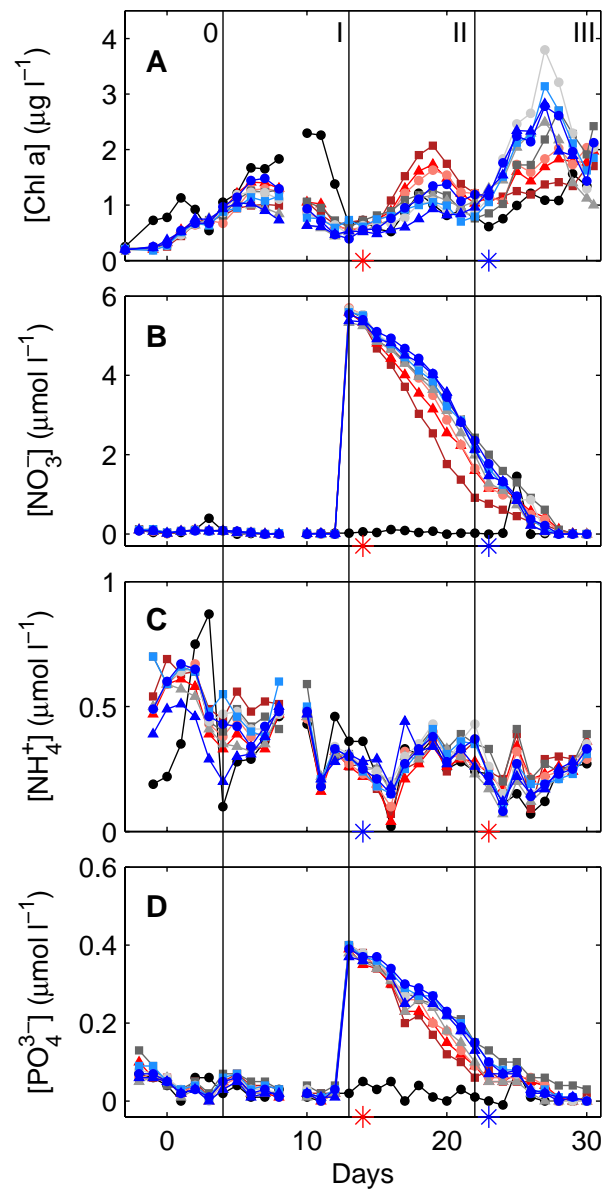

Fig. 6. Temporal development of depth-averaged (0.3-12 m) Chl $a$ (A), nitrate (B), ammonium (C) and phosphate (D) concentrations in each mesocosm and the fjord. For symbols and colour code, see Table 1. Vertical black lines and Roman numbers illustrate the three phases after $\mathrm{CO}_{2}$ perturbation while 0 refers to the phase prior to this event. Red and blue stars denote statistically significant positive and negative correlations during a certain phase, respectively. For details on and results of the statistics applied, see Sect. 2.7 and Table 2. Note that statistics for nitrate and phosphate was done on rates, not the actual concentrations.

\subsection{Temporal chlorophyll $a$ dynamics}

Depth-averaged (0.3-12 m) chlorophyll $a$ concentrations inside the mesocosms and the fjord started at about $0.2 \mu \mathrm{g} \mathrm{L}^{-1}$ on day $t-3$ and steadily increased to about $1-1.4 \mu \mathrm{g} \mathrm{L}^{-1}$ in the mesocosms until day $t 6-8$ (Fig. 6a). After that peak, chlorophyll $a$ levels declined again to almost starting concentrations on day $t 13$. Dissolved inorganic nutrient addition on that day (see next section for details) initiated a second phytoplankton bloom, with higher chlorophyll $a$ levels of up to $2 \mu \mathrm{g} \mathrm{L}^{-1}$ in the highest $\mathrm{CO}_{2}$ treatment in comparison to about $1 \mu \mathrm{g} \mathrm{L}^{-1}$ in one of the control mesocosms on day $t 19$. After the collapse of the second bloom, a third developed, but this time building up higher chlorophyll $a$ concentrations in the mesocosms with lower in comparison to higher $\mathrm{CO}_{2}$ levels.

Based on the temporal development of chlorophyll $a$ dynamics, four distinct phases were defined: phase 0 (from the start of the experiment to the end of the $\mathrm{CO}_{2}$ addition, $t-4$ to $t 4$ ), phase I (from the end of $\mathrm{CO}_{2}$ enrichment to the end of the first bloom, $t 4$ to $t 13$ ), phase II (from the end of the first bloom to the end of the second bloom, $t 13$ to $t 22$ ) and phase III (from the end of the second bloom to the end of the experiment, $t 22$ to $t 30$ ). Chlorophyll $a$ concentrations showed a statistically significant linear correlation with $\mathrm{CO}_{2}$ levels in phase II, while it was negative during phase III (Fig. 6a and Table 2).

In the fjord, temporal chlorophyll $a$ dynamics were initially similar to those in the mesocosms, although reaching higher levels and peaking a few days later (Fig. 6a). Interestingly, there were signs of a second and the beginning of a third bloom phase in the fjord with similar timing as in the mesocosms, however, at lower intensities.

\subsection{Dissolved inorganic nutrient dynamics with time}

Initial nitrate $\left(\mathrm{NO}_{3}^{-}\right)$concentrations in the mesocosms were close to detection limit (about $0.1 \mu \mathrm{mol} \mathrm{L}{ }^{-1}$ ) and remained that low until the addition of dissolved inorganic nutrients on day $t 13$. Initial ammonium $\left(\mathrm{NH}_{4}^{+}\right)$and phosphate $\left(\mathrm{PO}_{4}^{3-}\right)$ concentrations in the mesocosms were measured at about $0.5-0.7 \mu \mathrm{mol} \mathrm{L}^{-1}$ and $0.06-0.09 \mu \mathrm{mol} \mathrm{L}^{-1}$, respectively. While ammonium steadily decreased from then on, most of the phosphate initially present was taken up in the first couple of days (Fig. 6b-d).

Additions of dissolved inorganic nutrients on day $t 13 \mathrm{in}$ creased $\mathrm{NO}_{3}^{-}$and $\mathrm{PO}_{4}^{3-}$ concentrations to about 5.5 and $0.4 \mu \mathrm{mol} \mathrm{L}-1$, respectively. $\mathrm{NO}_{3}^{-}$and $\mathrm{PO}_{4}^{3-}$ were then readily taken up by the plankton community, declining towards detection limits until the end of the experiment. Immediately after nutrient addition, however, nutrient utilization of both $\mathrm{NO}_{3}^{-}$and $\mathrm{PO}_{4}^{3-}$ was faster at higher $\mathrm{CO}_{2}$ levels during phase II, while being slower during phase III (Fig. 6b and d). This observation was statistically significant. $\mathrm{NH}_{4}^{+}$concentrations were also correlated to $\mathrm{CO}_{2}$ level in a statistically significant manner, negatively in phase II and positively in phase III of the experiment (Fig. 6c and Table 2).

Dynamics of $\mathrm{NO}_{3}^{-}, \mathrm{PO}_{4}^{3-}$ and $\mathrm{NH}_{4}^{+}$in the fjord during phase 0 and $\mathrm{I}$ of the experiment were similar to those in the mesocosms. However, they remained at relatively low levels also in phase II and III (Fig. 6c).

\subsection{Silicate addition and silicon budget}

Prior to the addition of dissolved inorganic nutrients on day $t 13$, silicate concentrations, together with those of biogenic silica and total silicate (the sum of silicate and biogenic silica), were relatively stable in all mesocosms. However, during phase I there was a statistically significant correlation 


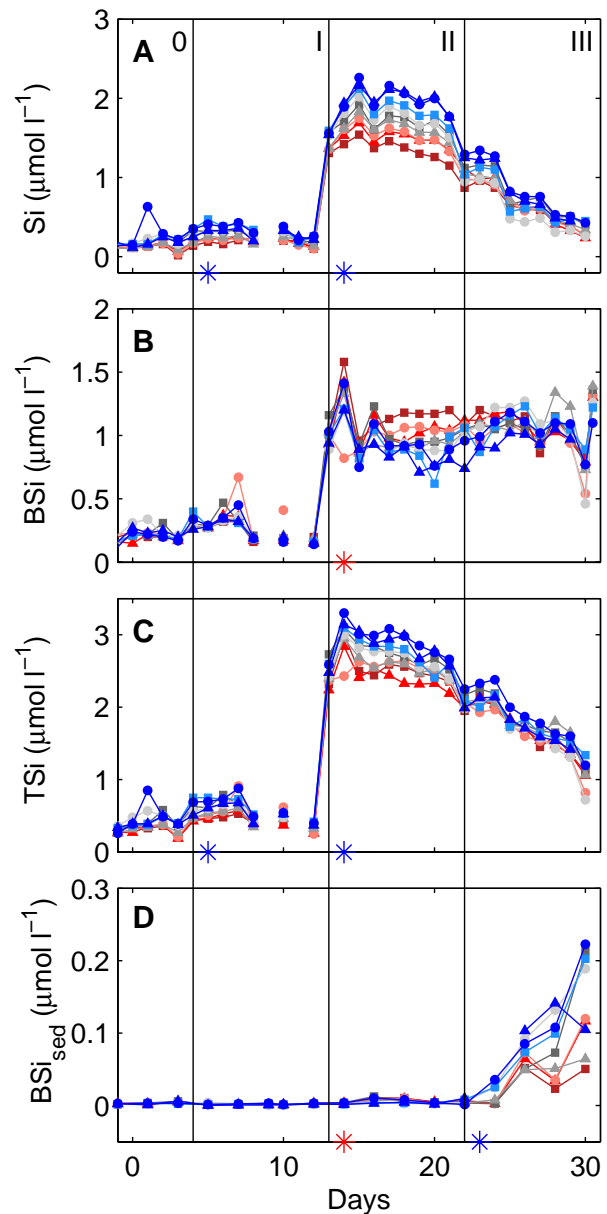

Fig. 7. Temporal development of depth-averaged (0.3-12 m) silicate (A), biogenic silicate (B), total silicate as the sum of silicate and biogenic silicate $(\mathbf{C})$, and sedimented biogenic silicate concentrations (D). For details on sediment sampling and processing, see Czerny et al. (2012a). Style and colour code follow those of Fig. 6, and statistical results are summarized in Table 2.

of silicate and total silicate with $\mathrm{CO}_{2}$, with higher concentrations towards lower $\mathrm{CO}_{2}$ (Fig. 7a, c, and Table 2). The addition of silicate (targeted for about $2.5 \mu \mathrm{mol} \mathrm{L}^{-1}$ ) on day $t 13$ to all mesocosms increased concentrations to only about $1.3-1.6 \mu \mathrm{mol} \mathrm{L}^{-1}$. The rest of the added silicate was in a precipitated form and increased biogenic silica concentrations to about $0.8-1.2 \mu \mathrm{mol} \mathrm{L}^{-1}$. In the first days after the nutrient addition, silicate continued to increase in all mesocosms, reaching higher concentrations at lower $\mathrm{CO}_{2}$ levels, but then steadily declined towards the end of the experiment. While silicate concentrations in phase II displayed a statistically significant negative correlation to $\mathrm{CO}_{2}$, those of biogenic silica were positively correlated (Fig. 7a, b, and Table 2). During that phase, also the amount of biogenic silica collected in the sediment traps was higher at higher $\mathrm{CO}_{2}$ levels, although absolute amounts were relatively small compared to water column inventories (Fig. 7d). This trend reversed in
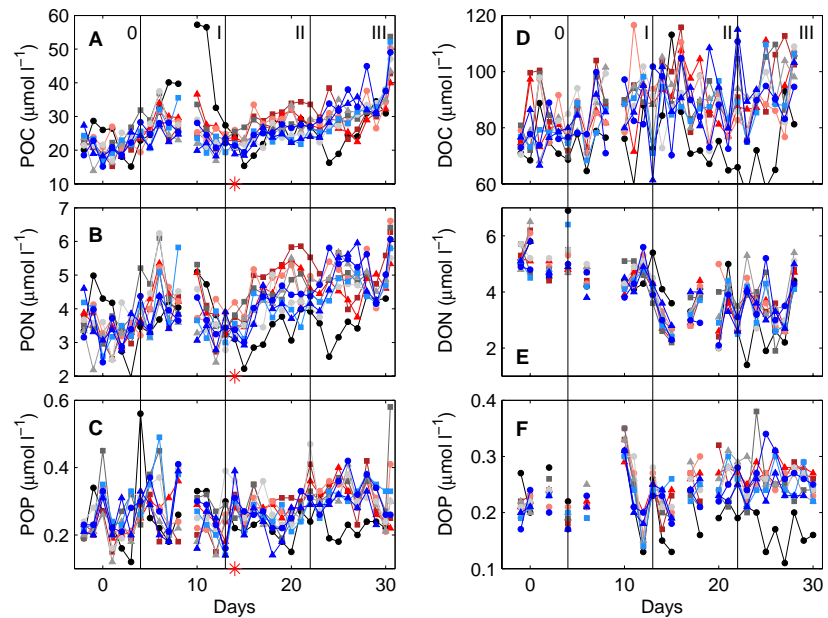

Fig. 8. Temporal development of depth-averaged (0.3-12 m) particulate organic carbon (A), nitrogen (B) and phosphorus (C), together with dissolved organic carbon (D), nitrogen (E) and phosphorus $(\mathbf{F})$ concentrations. Style and colour code follow those of Fig. 6, and statistical results are summarized in Table 2.

phase III, when more biogenic silicate at lower $\mathrm{CO}_{2}$ levels was collected in the sediment traps (again at relatively low concentrations), at a time when no $\mathrm{CO}_{2}$ effect was observed on any of the water column silica components (Fig. 7).

\subsection{Particulate and dissolved organic matter dynamics with time}

Initial concentrations of particulate organic carbon (POC), nitrogen (PON) and phosphorus (POP) started at about $15-25 \mu \mathrm{mol} \mathrm{L}^{-1}, 3-4 \mu \mathrm{mol} \mathrm{L}^{-1}$ and $0.2-0.3 \mu \mathrm{mol} \mathrm{L}^{-1}$, respectively (Fig. 8a-c). POC and PON peaked during phase I of the experiment, similar to chlorophyll $a$. However, this observation was less evident for POP. Both POC and PON increased after nutrient addition in phase II and III, and again this was less obvious for POP. During phase II, standing stocks of POC, PON and POP were positively correlated to $\mathrm{CO}_{2}$. This trend was statistically significant (Table 2).

While temporal dynamics of POC, PON and POP were basically identical, those of dissolved organic carbon (DOC), nitrogen (DON) and phosphorus (DOP) were quite different. DOC, starting at about $70-80 \mu \mathrm{mol} \mathrm{L}^{-1}$ in all mesocosms, increased before nutrient addition during phase 0 and $\mathrm{I}$. As a result, there was a tendency towards higher DOC concentrations at higher $\mathrm{CO}_{2}$ in phase II, although statistically not significant (Table 2). After nutrient addition, however, there seemed to be no further DOC accumulation (Fig. 8d). In contrast, DON, starting at about $5-6 \mu \mathrm{mol} \mathrm{L}^{-1}$ in all mesocosms, steadily declined before nutrient addition during phase 0 and $\mathrm{I}$ by about $1 \mu \mathrm{mol} \mathrm{L}{ }^{-1}$, and remained rather constant from then on, although with considerable scatter in the data (Fig. 8e). Finally, DOP concentrations, starting at about $0.2 \mu \mathrm{mol} \mathrm{L}^{-1}$ in all mesocosms, seemed rather constant 

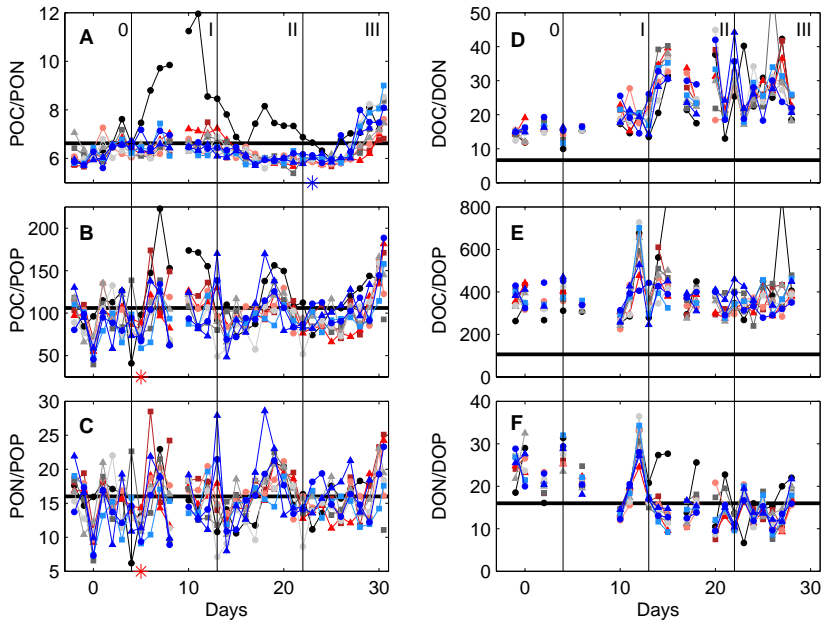

Fig. 9. Temporal development of depth-averaged $(0.3-12 \mathrm{~m})$ ratios of particulate organic carbon to nitrogen (A), particulate organic carbon to phosphorus (B), particulate organic nitrogen to phosphorus (C), dissolved organic carbon to nitrogen (D), dissolved organic carbon to phosphorus (E), and dissolved organic nitrogen to phosphorus (F). Horizontal black lines denote elemental ratios according to Redfield et al. (1963). Style and colour code follow those of Fig. 6, and statistical results are summarized in Table 2.

during phase 0 and I, but increased after nutrient addition by $0.05-0.1 \mu \mathrm{mol} \mathrm{L}^{-1}$ in all mesocosms during phase II, and then remained rather stable until the end of the experiment (Fig. 8f).

Dynamics of particulate and dissolved organic element concentrations in the fjord were similar to those in the mesocosms during phase 0 and I, with the exception of POC, which peaked at higher concentrations (Fig. 8). However, after nutrient addition, absolute concentrations tended to be smaller.

\subsection{Temporal dynamics of particulate and dissolved organic element stoichiometry}

POC/PON started slightly below the classical Redfield stoichiometry $(\mathrm{C} / \mathrm{N} / \mathrm{P}$ of $106: 16: 1)$ in all mesocosms and increased during phase I (Fig. 9a). Nutrient addition at the beginning of phase II decreased POC/PON back below the Redfield ratio. However, during the end of phase III, POC/PON started to increase again, towards higher ratios at lower $\mathrm{CO}_{2}$. This trend in phase III was statistically significant (Table 2).

Both POC/POP and PON/POP were close to the respective Redfield ratio during the entire experiment, although with considerable scatter in the data (Fig. $9 \mathrm{~b}$ and c). Mesocosms with higher $\mathrm{CO}_{2}$ had higher POC/POP and PON/POP in phase II, an observation that was statistically significant (Table 2). During the last days of the experiment, POC/POP started to increase in all mesocosms.

Both, DOC/DON and DOC/DOP started (and remained) well above classical Redfield stoichiometry in all mesocosms
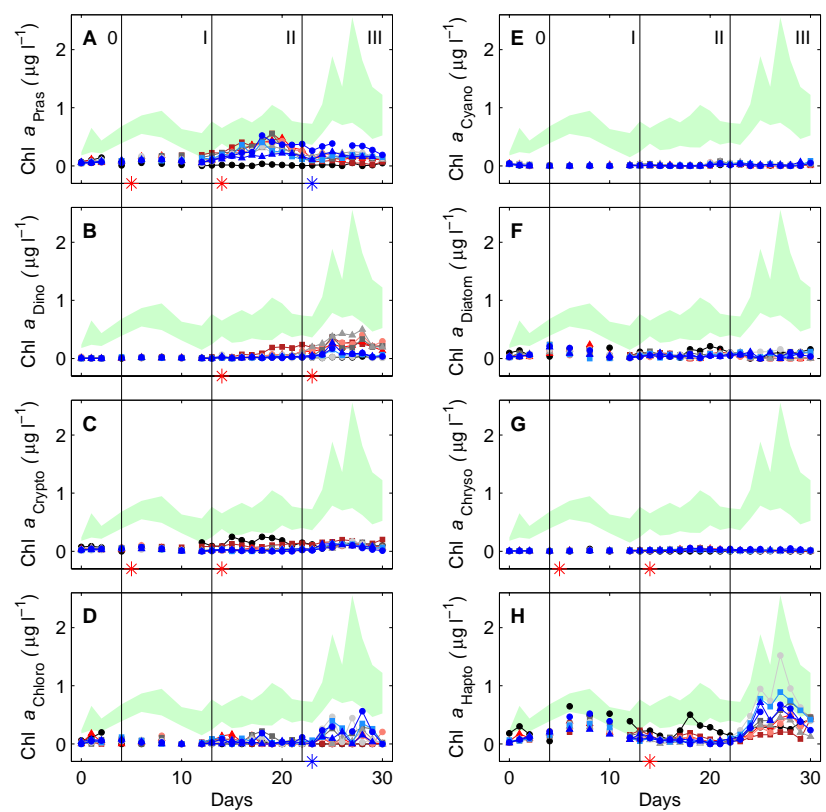

Fig. 10. Temporal development of depth-averaged (0.3-12 m) Chl $a$ equivalent concentrations of prasinophytes (A), dinoflagellates (B), cryptophytes $(\mathbf{C})$, chlorophytes $(\mathbf{D})$, cyanobacteria $(\mathbf{E})$, diatoms $(\mathbf{F})$, chrysophytes (G) and haptophytes (H) as analysed by HPLC and CHEMTAX (see Materials and Methods section for details). Green shaded area illustrates minima and maxima of total Chl $a$ concentrations in the mesocosms. Style and colour code follow those of Fig. 6, and statistical results are summarized in Table 2.

(Fig. 9d and e). While DOC/DON steadily increased during phase 0 and I and remained rather constant during phase II and III, DOC/DOP relatively quickly increased towards the end of phase I and then declined throughout phase II, stabilizing again in phase III. DON/DOP also started well above classical Redfield stoichiometry in all mesocosms, but then rather steadily declined throughout the experiment and stabilized towards the end slightly below its respective ratio (Fig. 9f).

Temporal dynamics of particulate and dissolved organic element stoichiometry in the fjord were similar to those in the mesocosms. An exception were absolute ratios of POC to PON, being higher during phase I and II (Fig. 9).

\subsection{Temporal changes in phytoplankton community composition derived from HPLC analysis of marker pigments}

Chl $a$ as measured by HPLC followed the same temporal evolution, and most importantly with the same $\mathrm{CO}_{2}-$ related trends between treatments as the fluorometric determinations, although at slightly lower absolute concentrations (Figs. 6a and 10).

According to CHEMTAX analysis, the Chl $a$ peak during phase I was mostly due to the presence of haptophytes, with 

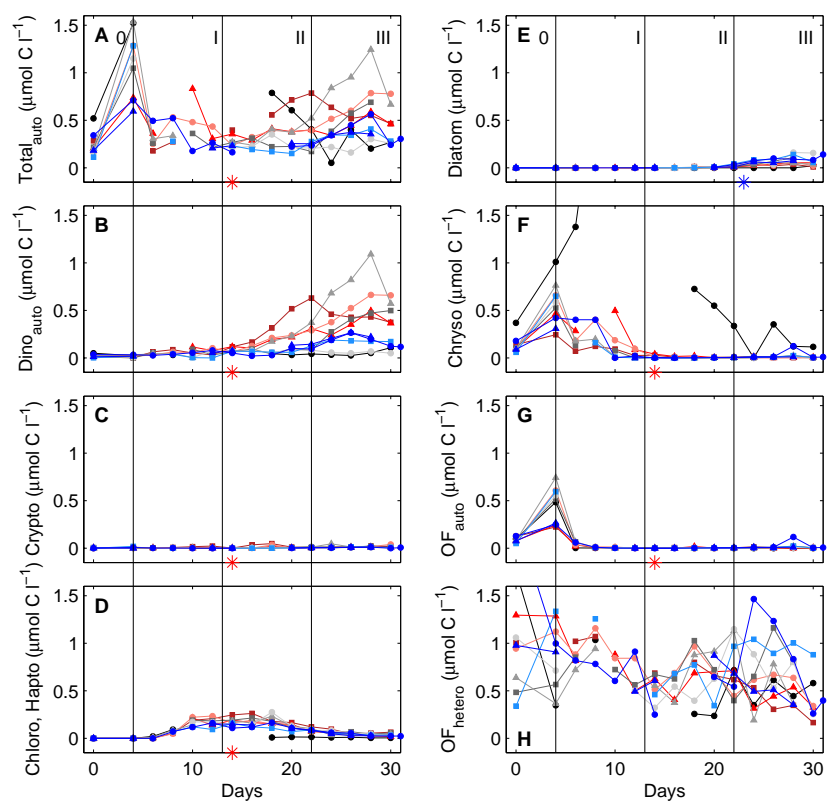

Fig. 11. Temporal development of depth-averaged $(0.3-12 \mathrm{~m})$ plankton carbon biomass of all autotrophs (A), autotrophic dinoflagellates (B), cryptophytes (C), chlorophytes or haptophytes (D), diatoms (E), chrysophytes (F), autotrophic flagellates other than dinoflagellates $(\mathbf{G})$, and heterotrophic flagellates $(\mathbf{H})$ as counted by light microscopy. Style and colour code follow those of Fig. 6, and statistical results are summarized in Table 2.

minor contributions of prasinophytes and diatoms (Fig. 10h, $\mathrm{a}$ and $\mathrm{f}$, respectively). The second Chl $a$ peak during phase II was dominated by the bloom of prasinophytes, dinoflagellates (especially at higher $\mathrm{CO}_{2}$ levels) and cryptophytes (Fig. 10a-c, respectively). Finally, the third Chl $a$ peak in phase III was driven by the growth of haptophytes, prasinophytes, dinoflagellates and chlorophytes, with the former being responsible for about half of autotrophic biomass (Fig. 10h, a, b and d, respectively). Cyanobacteria and chrysophytes contributed only marginally to the autotrophic biomass throughout the experiment (Fig. 10e and g). There were several statistically significant $\mathrm{CO}_{2}$ effects on phytoplankton biomass, such as positive $\mathrm{CO}_{2}$ correlations for prasinophytes, cryptophytes and chrysophytes (phase I and II), dinoflagellates (phase II and III) and haptophytes (phase II), and negative $\mathrm{CO}_{2}$ correlations for prasinophytes and chlorophytes in phase III (Table 2).

Temporal phytoplankton dynamics as revealed by HPLC in the fjord was similar to the mesocosms for most groups, although at lower absolute biomass. An exception were prasinophytes and dinoflagellates, important contributors to autotrophic standing stocks in all mesocosms during phase II and III, having insignificant contributions in the fjord during this time (Fig. 10).

\subsection{Temporal changes in plankton community composition as determined by light microscopy}

As determined by microscopic counts, most autotrophic carbon biomass during phase I was found in chrysophytes and chlorophytes, although the latter could have been also Phaeocystis, belonging to the group of haptophytes (Fig. 11). During phase II most autotrophic carbon was found to be in dinoflagellates and again the chlorophytes (or haptophytes). Finally, phase III was clearly dominated by autotrophic dinoflagellates, with minor contributions by diatoms. As for HPLC-derived phytoplankton community composition, there were statistically significant trends with $\mathrm{CO}_{2}$, positive ones for autotrophic dinoflagellates, cryptophytes, chlorophytes (or haptophytes), chrysophytes and autotrophic flagellates other than dinoflagellates in phase II. During phase III carbon biomass by diatoms was higher at lower $\mathrm{CO}_{2}$ levels, a trend found to be statistically significant (Table 2). It has to be noted, however, that $\mathrm{CO}_{2}$ was most likely indirectly influencing diatom biomass (see Sect. 4.2.2 for details).

Compared to total autotrophic carbon, similar amounts (between 0.5 and $1.5 \mu \mathrm{mol} \mathrm{L}^{-1}$ ) were found in heterotrophic flagellates (Fig. 11h). However, concentrations seemed to slightly decline during phase $\mathrm{I}$ in all mesocosms, while the dynamics during phase III appeared to be varying between mesocosms, although with no particular $\mathrm{CO}_{2}$ trend.

Dynamics of plankton carbon standing stocks in the fjord were similar to those in the mesocosms, but usually at lower absolute concentrations (Fig. 11). An exception were autotrophic dinoflagellates with insignificant and chrysophytes with higher carbon biomass in comparison to the mesocosms at certain times.

\subsection{First- and second-stage analyses}

First-stage MDS (multi-dimensional scaling) plots for the combined CHEMTAX and Chl $a$ dataset showed no clear succession pattern between the control and the $\mathrm{CO}_{2}$-treated mesocosms (Fig. 12a). Furthermore, the two control mesocosms (M3 and M7) had rather different patterns concerning their time trajectories, indicating natural variability of the enclosed plankton assemblages. Only the time trajectory of mesocosm M9 had a clear succession in the temporal evolution, in contrast to the others. Based on this, it is not clear whether there was a $\mathrm{CO}_{2}$ effect on the temporal development of the phytoplankton community or whether it was masked by slightly different starting conditions. The second-stage MDS plot showed no clear separation between the control and treated mesocosms, probably related to differences between the controls. However, a differentiation according to $\mathrm{CO}_{2}$ level is obvious. This was confirmed by the RELATE analysis, identifying the temporal pigment (CHEMTAX and $\mathrm{Chl} a$ ) evolution, when the entire experiment was considered, to be statistically different and related to $\mathrm{CO}_{2}$, at a significance level of 0.001 (Table 3). 

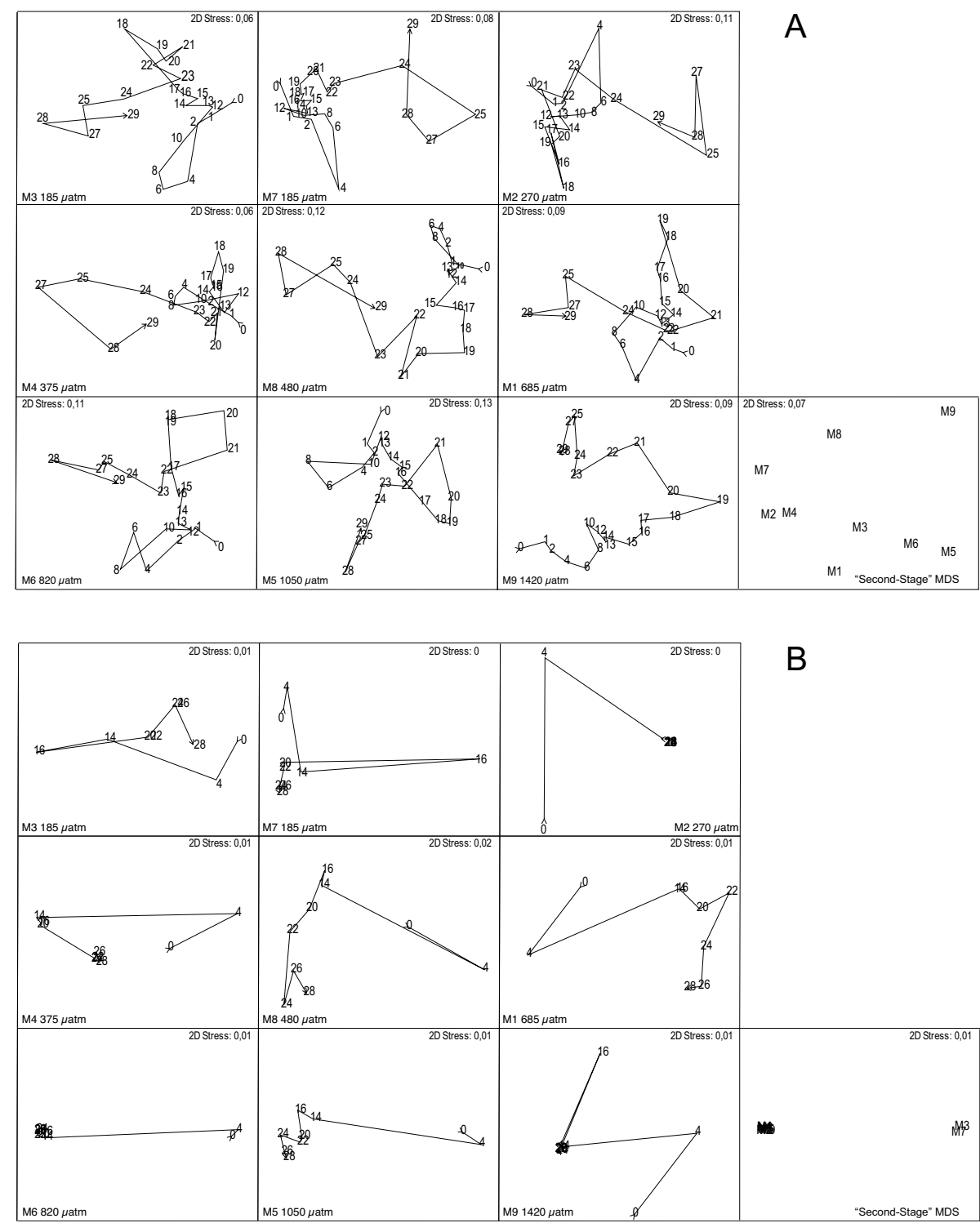

Fig. 12. First-stage MDS time trajectories and second-stage MDS plots from analyses of the CHEMTAX together with Chl $a$ (A), and phytoplankton carbon biomass datasets (B). See Sect. 2.7.2 for details.

Table 3. Significance levels of the RELATE analyses for the CHEMTAX and Chl $a$, phytoplankton carbon biomass, and organics (POC, PON, POP, DON and DOP) datasets. While a dashed line indicates that there were too few observations for an analysis, bold numbers highlight a statistical significance below the $5 \%$ level.

\begin{tabular}{lrrr}
\hline & CHEMTAX + Chl $a$ & Phytoplankton & Organics \\
\hline Phase 0 & - & - & - \\
Phase I & 0.425 & - & 0.943 \\
Phase II & 0.172 & - & 0.369 \\
Phase III & $\mathbf{0 . 0 2 3}$ & - & 0.11 \\
\hline Phase 0-III & $\mathbf{0 . 0 0 1}$ & $\mathbf{0 . 0 4 8}$ & 0.222 \\
\hline
\end{tabular}

First-stage MDS plots for the phytoplankton carbon biomass dataset showed a more consistent pattern among time trajectories of the control and treated mesocosms (Fig. 12b). In this respect, the two control mesocosms were considerably more similar as compared to those of the CHEMTAX and Chl $a$ dataset and revealed also differences in their temporal evolution compared to the $\mathrm{CO}_{2}$-treated mesocosms. For example, the days 14 and 16 plot far apart from each other in the control mesocosms M3 and M7, while the days 20 and 22 plot very close together. This was, with the exception of M5 and M9, not the case for the $\mathrm{CO}_{2}$-treated mesocosms. As a result, the second-stage MDS plot, depicting similarity of the time trajectories among the mesocosms, clearly separated the control from the $\mathrm{CO}_{2}$-treated 
mesocosms. The RELATE analysis confirmed this observation, when the entire experiment was considered, identifying the temporal carbon biomass dynamics to be statistically different and related to $\mathrm{CO}_{2}$, at a significance level of 0.048 (Table 3).

While the RELATE analysis, considering the entire experiment, identified the temporal development of phytoplankton pigments (CHEMTAX) and Chl $a$, and that of phytoplankton carbon biomass to be statistically different and related to $\mathrm{CO}_{2}$, the dynamics in the organics dataset were not different at a statistically significant level (Table 3 ). Considering individual phases of the experiment, the temporal evolution of phytoplankton pigments (CHEMTAX) and Chl $a$ was statistically different and related to $\mathrm{CO}_{2}$ in phase III. Interestingly, while calculated levels of significance of the RELATE analyses were relatively high in the beginning of the experiment in phase I (thus not statistically significant), they steadily decreased throughout phase II and III.

\section{Discussion}

\subsection{Oceanographic setting}

At the beginning of the experiment, the plankton community was clearly in a post-bloom phase, indicated by high $\mathrm{O}_{2}$ and $\mathrm{pH}$, and low $p \mathrm{CO}_{2}$ levels in the water column. Oxygen levels were supersaturated by about $140 \mu \mathrm{mol} \mathrm{kg}^{-1}$ in comparison to dissolved inorganic carbon (DIC), being under-saturated by about the same amount, when taking initial measured mean total alkalinity (TA) and DIC and calculating DIC in atmospheric equilibrium using the dissociation constants for carbonic acid by Mehrbach et al. (1973) at in situ temperature and salinity (for details on carbonate chemistry, see Bellerby et al., 2012). Considering that autotrophic growth, depending on nitrogen source, is typically producing $1-1.4 \mathrm{~mol}$ oxygen per mole DIC consumed (Laws, 1991), and that oxygen exchanges with the atmosphere about ten times faster than carbon dioxide (Broecker and Peng, 1982), a phytoplankton bloom came to an end probably just a couple of days before the beginning of the experiment.

The relatively substantial amounts of ammonia in comparison to nitrate are indicative of a recycling system, typical for this location and time of the year (Iversen and Seuthe, 2011). The autotrophic community did not appear to be nutrient limited, as indicated by particulate organic carbon to nitrogen (POC/PON) below classical Redfield stoichiometry (Redfield et al., 1963), although most of the particulate organic matter was probably not in the autotrophic but rather heterotrophic compartment or detritus, as initial POC to Chl $a$ ratios $(\mu \mathrm{mol} / \mu \mathrm{g})$ were well above 100 . Typical ratios for phytoplankton range between 3 and 8 (Montagnes et al., 1994). Nevertheless, the increase in Chl $a$ during phase 0 and I in all mesocosms is further indication that autotrophic biomass was initially not nutrient limited.
During the experimental period, considerable variability in salinity was measured in the fjord, being as low as 29.59 at the surface and up to 34.29 in $12 \mathrm{~m}$ depth. This was probably the result of changing relative influence of Arctic and Atlantic water masses and meltwater runoff (Hop et al., 2006). Despite this water mass variability, general characteristics in plankton bloom development in the fjord were surprisingly similar to those in the mesocosms (see Sect. 4.6 for details).

\subsection{Autotrophic biomass and nutrient dynamics}

During phase 0 and then $\mathrm{I}$, after $\mathrm{CO}_{2}$ manipulation, a first phytoplankton bloom developed in all mesocosms, however, with no particular effect of $\mathrm{CO}_{2}$ on actual concentrations of $\mathrm{Chl} a$ or particulate organic matter (Figs. 6a, and $8 \mathrm{a}-\mathrm{c}$ ). Taking the mean of all mesocosms, utilization of $\sim 0.05, \sim 0.2$ and $\sim 0.7 \mu \mathrm{mol} \mathrm{L}{ }^{-1}$ of phosphate, ammonium and DON, respectively, explain reasonably well the build-up of $\sim 9 \mu \mathrm{mol} \mathrm{L}{ }^{-1}$ of POC during this time. Considering measurement uncertainties at such low nutrient concentrations and the relatively small POC production at much higher background levels, the bloom can be thought to have followed conventional Redfield proportions (Redfield et al., 1963), although carbon quotas seem elevated. The resulting POC to Chl $a$ ratio $(\mu \mathrm{mol} / \mu \mathrm{g}$ ) of $\sim 9$ (Figs. 6a and $8 \mathrm{a}$ ) is about twice as high and at the upper range of reported values for marine phytoplankton (Montagnes et al., 1994). This indicates that a significant portion of the freshly produced autotrophic biomass was consumed by heterotrophic grazing, although not reflected by protozooplankton biomass during that time (Aberle et al., 2012). However, cirripedia nauplii, dominating the mesozooplankton community in this phase, grew to cypris larvae, the next developmental stage (Niehoff et al., 2012), and uptake of ${ }^{13} \mathrm{C}$-labelled autotrophic material by both cirripedia nauplii and copepods was observed (de Kluijver et al., 2012). Furthermore, grazing by microzooplankton on nanoeukaryotes, an important phytoplankton component in this phase, probably haptophytes (Fig. 10h), was measured (Brussaard et al., 2012). Apart from grazing, viral lysis of phytoplankton was found to contribute to the termination of the first bloom (Brussaard et al., 2012).

\subsubsection{Direct effects of $\mathrm{CO}_{2}$ on marine phytoplankton}

Interestingly, a positive effect of $\mathrm{CO}_{2}$ on abundances of prasinophytes, probably identified by flow cytometry as picoeukaryotes (Brussaard et al., 2012), started to develop already in phase I. Nutrient addition on day $t 13$ amplified this trend, and prasinophytes, dominating the phytoplankton community in terms of biomass during phase II, clearly profited from higher $\mathrm{CO}_{2}$ levels (also compare Brussaard et al., 2012). Associated dissolved inorganic nutrient drawdown of nitrate, phosphate and ammonium during the first part of phase II was also higher (Fig. 6b-d). This can fully be explained by higher autotrophic biomass build-up during this 
time. Assuming a mean carbon to $\mathrm{Chl} a$ ratio of $4(\mu \mathrm{mol} / \mu \mathrm{g})$ for autotrophic growth (Montagnes et al., 1994) would result in a nitrogen to Chl $a$ ratio of about $0.6(\mu \mathrm{mol} / \mu \mathrm{g})$, meaning that, for $1 \mu \mathrm{g} \mathrm{L}^{-1}$ of $\mathrm{Chl} a$ produced, $0.6 \mu \mathrm{mol} \mathrm{L}^{-1}$ of nitrate (or ammonium) is taken up. Differences in maximum $\mathrm{Chl} a$ levels and nutrient utilization between $\mathrm{CO}_{2}$ treatments were indeed on this order of magnitude (Fig. 6). Such direct effect of $\mathrm{CO}_{2}$ on picoeukaryotes, most likely belonging to the group of prasinophytes, was also found in other mesocosm experiments where especially Micromonas-like (s.i.c.) phylotypes profited from higher $\mathrm{CO}_{2}$ levels (Paulino et al., 2008; Engel et al., 2008; Meakin and Wyman, 2011; Newbold et al., 2012). The reason for such pronounced $\mathrm{CO}_{2}$ sensitivity could be speculated to be related to the mode of the cellular carbon concentrating mechanism (CCM) employed. Micromonas is known to operate a C-4-like carbon fixation pathway (Worden, 2009) and to express extra-cellular carbonic anhydrase (Iglesias-Rodríguez et al., 1998), facilitating the otherwise slow inter-conversion between carbon dioxide $\left(\mathrm{CO}_{2}\right)$ and bicarbonate $\left(\mathrm{HCO}_{3}^{-}\right)$. However, its relatively small size (less than $2 \mu \mathrm{m}$ in diameter) could make the extensive operation of active $\mathrm{CO}_{2}$ and $\mathrm{HCO}_{3}^{-}$uptake, like in most bigger phytoplankton species (e.g. Giordano et al., 2005 and references therein), unnecessary as the diffusive boundary layer can be considered relatively small (Riebesell et al., 1993). Thus, if cells are so small that dissolved inorganic carbon supply can at least partly be met by diffusion, higher seawater $\mathrm{CO}_{2}$ concentrations could stimulate photosynthetic carbon fixation and growth in these species. In other words, species that are not able to saturate photosynthesis at current $\mathrm{CO}_{2}$ levels might directly profit from increasing seawater concentrations, like the picophytoplankton smaller $2 \mu \mathrm{m}$ in this study. However, what applies to the very small species might also apply to the very big ones as suggested by Tortell et al. (2008) who found larger diatoms (Chaetoceros) to profit from increasing seawater $\mathrm{CO}_{2}$ concentrations at the expense of smaller, although still comparatively big ones (Pseudo-nitzschia).

Also autotrophic dinoflagellates, as identified by microscopic counts and HPLC pigment analysis, profited from higher $\mathrm{CO}_{2}$ during phase II (Fig. 11b). As they appear to possess only moderately efficient CCMs (see Reinfelder (2010) for a review and references therein), they also can be regarded as potential winners in the phytoplankton community at increasing levels of carbon dioxide.

\subsubsection{Indirect effects of $\mathrm{CO}_{2}$ on marine phytoplankton}

As the termination of the first bloom in phase I, also that of the second bloom in phase II was probably connected to viral infection. Flow cytometry identified two distinct virus clusters appearing, of which one correlated with the decline of the dominant nanophytoplankton cluster in phase I and the other with the dominant picophytoplankton cluster in phase II (see Brussaard et al., 2012 for details).
During phase III of the experiment, the positive $\mathrm{CO}_{2}$ effect on autotrophic biomass observed in phase II reversed (Fig. 6a). Now diatoms, prasinophytes and to a certain extent also haptophytes grew to higher abundances at low in comparison to high $\mathrm{CO}_{2}$ (Figs. 10 and 11e). This is most likely an indirect $\mathrm{CO}_{2}$ effect as, after the collapse of the second bloom in phase II, more inorganic nutrients were available at lower $\mathrm{CO}_{2}$ concentrations (Fig. $6 \mathrm{~b}$ and d). This was at a time when dissolved silicate concentrations were similar in all mesocosms (Fig. 7). As the silicic frustules of diatoms are known to efficiently ballast organic matter, facilitating the export to depth (Armstrong et al., 2001; Francois et al., 2002; Klaas and Archer, 2002, but see also Passow, 2004), higher diatom-derived biomass could be connected to the higher organic biomass collected in the sediment traps in the mesocosms with lower $\mathrm{CO}_{2}$ levels (see Czerny et al., 2012a for details). However, the experiment ended at a time of relatively high sedimentation and it is thus not clear if the observation of more export at lower $\mathrm{CO}_{2}$ would be a persistent signal. Nevertheless, global export production in the future and biomass transfer to higher trophic levels could be affected if more nutrients are being utilized by small picoplankton, profiting from enhanced $\mathrm{CO}_{2}$ levels, and rather being grazed by nano-/microzooplankton and remineralized in the surface ocean.

\subsection{Comparison of phytoplankton biomass determination approaches}

Although there are inherent uncertainties associated with converting phytoplankton counts to biovolume and relating this to organic matter standing stocks, according to microscopic counts, the carbon found in autotrophic biomass was relatively low in comparison to measured built-up of POC and Chl $a$ (Figs. 11, 8, and 6a). Part of this seeming discrepancy could be connected to biomass transfer to higher trophic levels by grazing (compare Czerny et al., 2012a; Brussaard et al., 2012; de Kluijver et al., 2012; Aberle et al., 2012 and Niehoff et al., 2012, but also Sect. 4.2). Furthermore, phytoplankton pigment analysis revealed prasinophytes (potentially Micromonas-like phylotypes) and haptophytes to dominate the autotrophic biomass during most of the experiment, an observation not picked up by light microscopy. This is probably related to their small size as Micromonas is less than $2 \mu \mathrm{m}$ in diameter and most of the haptophyte carbon is usually found in the size class below $3 \mu \mathrm{m}$, often dominating overall marine autotrophic biomass in the ocean (Lui et al., 2009; Uitz et al., 2010; Cuvelier, 2010). The dominance of picophytoplankton in certain phases of the experiment was confirmed by flow cytometry (see Brussaard et al., 2012 for details). 


\subsection{Temporal dynamics of particulate organic matter}

Temporal dynamics, especially effects of $\mathrm{CO}_{2}$, in and on standing stocks of particulate organic matter was not as clear as for Chl $a$ and phytoplankton community composition (Figs. 8, 6a, 10 and 11). Given measurement uncertainties and relatively low autotrophic production on a relatively large particulate organic matter background, trends clearly seen in the autotrophic compartments only become visible in particulate organic matter dynamics when phytoplankton growth exceeds a certain threshold (also compare Kim et al., 2011), like after nutrient addition in phase II (Fig. 8a-c). Thus, the observation that there was no measurable effect of $\mathrm{CO}_{2}$ on standing stocks of particulate organic matter such as carbon, observed in several mesocosm studies, does not allow the conclusion that autotrophic carbon built-up was not affected (compare Engel et al., 2005; Schulz et al., 2008). This also applies to stoichiometric ratios of particulate and dissolved organic matter. To directly observe carbon utilization by phytoplankton and identify potential $\mathrm{CO}_{2}$ effects, tracers such as ${ }^{13} \mathrm{C}$ provide much better insights (compare de Kluijver et al., 2010, 2012).

\subsection{Temporal development of $\mathrm{CO}_{2}$ effects}

There are numerous standing stock or plankton assemblage composition parameters that were positively or negatively correlated with $\mathrm{CO}_{2}$, sometimes even reversing from one to another phase. Interestingly, taking most of them together in a MDS and subsequent RELATE analysis shows that $\mathrm{CO}_{2}$ related differences between mesocosms become increasingly significant with time (Table 3). For instance, although statistically not significant in phase I and II, significance levels of the RELATE analysis for the combined CHEMTAX and Chl $a$ dataset steadily decreased from $0.425,0.172$ to 0.023 in phase I, II and III, respectively. Thus, it seems that $\mathrm{CO}_{2}$ related differences slowly develop with time, becoming more and more pronounced and, consequently, statistically significant only after a certain period of time. The time necessary to detect such differences is probably connected to generation and turn-over times of the enclosed plankton communities and organic material. In this respect, the finding that increasing temperatures (ranging between 2.5 and $8.5^{\circ} \mathrm{C}$ ) did not affect particulate maximum built-up of organic carbon and Chl $a$ during a Baltic phytoplankton bloom in winter/spring (Wohlers et al., 2009) as opposed to a summer bloom (temperatures ranging between 9.5 to $17.5^{\circ} \mathrm{C}$ ) at the same location (Taucher et al., 2012) could be connected to higher turnover times at absolute higher temperatures and more rapidly evolving differences between treatments. However, different $\mathrm{CO}_{2}$ sensitivities of the dominating phytoplankton species in these two experiments cannot be ruled out (compare Taucher et al., 2012).

Finally, it seems that dissolved inorganic nutrients can be thought of as an amplifier. Upon addition, potential differ- ences, for instance in phytoplankton community structure, too small to be detected at a statistically significant level, would be amplified during phytoplankton biomass build-up (as observed in this experiment during phase II). However, if added right after $\mathrm{CO}_{2}$ manipulation, when differences between mesocosms are just starting to develop (as seen by the RELATE analysis), there is little to be amplified. This could be the reason why a previous experiment could only detect statistically significant differences in phytoplankton community composition in the declining but not the build-up phase of a bloom (Schulz et al., 2008). Interestingly, it was then again the picoeukaryotes profiting from higher $\mathrm{CO}_{2} \mathrm{lev}$ els, as observed in this experiment.

\subsection{Dynamics in the fjord in comparison to the mesocosms}

Concerning seasonal phytoplankton dynamics, a typical spring bloom, dominated by diatoms, usually develops in Kongsfjorden. Afterwards, into the summer season, the phytoplankton assemblage becomes more diverse and dinoflagellates, cryptophytes and small flagellates dominate the community (Hop et al., 2002; Halldal and Halldal, 1973). Furthermore, Keck et al. (1999) reported on the occurrence of unidentified flagellates smaller than $3 \mu \mathrm{m}$ during this time. It is, however, not clear whether the abundant small flagellates described in previous observations belong to the dominant groups of prasinophytes or haptophytes as identified here. Nevertheless, the general pattern of phytoplankton species composition after the spring bloom in this study seems to be typical for this time of the year.

As described in Sect. 4.1, significant salinity changes measured in the fjord are indicative of changing relative influence of Arctic and Atlantic water masses and meltwater runoff. Thus, one could expect that phytoplankton bloom dynamics and species composition would develop independently in the closed mesocosms. However, in the fjord general temporal dynamics in many measured parameters such as particulate organic matter, $\mathrm{Chl} a$, but also phytoplankton community structure (with some exceptions) was quite similar to those in the mesocosms, although occasionally at different absolute concentrations. For instance, Chl $a$ also peaked in the fjord during phase I, declined and increased again in phase II, followed by a decline and another increase in phase III, like in the mesocosms (Fig. 6a). This indicates that in the fjord at least similar processes, but most importantly triggers, were at operation, although water masses were constantly changing in comparison to the water masses enclosed in the mesocosms. As light and temperature were identical inside and outside the mesocosms, both are potential triggers for observed biomass dynamics, changing from averages of 444,586 to $392 \mu \mathrm{mol} \mathrm{m} \mathrm{s}^{-1}$ between phase I II and III, and from 3.3, 2.9 to $5.1^{\circ} \mathrm{C}$, respectively (Fig. 5c and 4). Other shaping factors are the development of viral abundances and grazing on the plankton community, mainly responsible for 
autotrophic biomass decline. Different dissolved inorganic nutrient availability inside the mesocosms and the fjord, especially during phase II and III, seemed rather to determine absolute biomass than influence the temporal dynamics. In this respect, although maybe surprising, mesocosms appear capable of reflecting natural processes and plankton succession at a certain location quite realistically, at least for a certain period of time.

\section{Conclusions}

Temporal dynamics of the natural plankton community present in the Arctic Kongsfjorden on the west coast of Spitsbergen (Norway) were generally well captured inside the nine mesocosms, manipulated for initial $\mathrm{CO}_{2}$ levels ranging between 185 to $1420 \mu$ atm (see Sect. 4.6 for details). Dissolved inorganic nutrients, added halfway through the experiment, amplified already established and developed $\mathrm{CO}_{2}-$ related differences in phytoplankton community composition (see Sect. 4.5 for details). Direct $\mathrm{CO}_{2}$ effects, most likely by impacting individual species performance, and indirect effects, most likely by species competition and interaction, were identified. Picophytoplankton smaller than $2 \mu \mathrm{m}$, probably belonging to the group of prasinophytes, directly profited from increased $\mathrm{CO}_{2}$ concentrations. Right after dissolved inorganic nutrient addition, this group utilized more inorganic nutrients and grew to higher biomass at higher $\mathrm{CO}_{2} \mathrm{lev}$ els (see Sect. 4.2.1 for details). Viral attack terminated this bloom and in the following nanophytoplankton, probably belonging to the group of haptophytes and dinoflagellates, started to dominate the phytoplankton community. This time, higher biomass was built-up at lower $\mathrm{CO}_{2}$ levels, an indirect effect caused by higher dissolved inorganic nutrient availability related to the reduced prior utilization by picophytoplankton at low in comparison to high $\mathrm{CO}_{2}$ (see Sect. 4.2.2 for details). In general, the observed $\mathrm{CO}_{2}$ effects developed slowly but steadily with time, becoming more and more statistically significant (see Sect. 4.5 for details). Although any mesocosm study is intrinsically a snapshot in space and time, general patterns seem to emerge. For instance, stimulating $\mathrm{CO}_{2}$ effects on picophytoplankton have been found already in several studies. If a bigger share of the dissolved inorganic nutrients available can be seized by this group, then future marine ecosystem functioning could be impacted by changes in energy transfer to higher trophic levels, remineralization patterns and export production, with potential feedbacks to the climate system.

\section{Supplementary material related to this article is

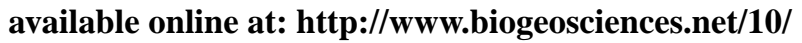 161/2013/bg-10-161-2013-supplement.zip.}

Acknowledgements. This work is a contribution to the "European Project on Ocean Acidification" (EPOCA), which received funding from the European Community's Seventh Framework Programme (FP7/2007-2013) under grant agreement no. 211384. Financial support was provided through Transnational Access funds by the European Union Seventh Framework Program (FP7/2007-2013) under grant agreement no. 22822 MESOAQUA and by Federal Ministry of Education and Research (BMBF, FKZ 03F0608) through the BIOACID (Biological Impacts of Ocean ACIDification) project. We gratefully acknowledge the logistical support of Greenpeace International for its assistance with the transport of the mesocosm facility from Kiel to $\mathrm{Ny}$-Ålesund and back to Kiel. We also thank the captains and crews of M/V ESPERANZA of Greenpeace and R/V Viking Explorer of the University Centre in Svalbard (UNIS) for assistance during mesocosm transport and during deployment and recovery in Kongsfjorden. We thank the staff of the FrenchGerman Arctic Research Base at Ny-Ålesund, in particular Marcus Schumacher, for on-site logistical support. S. Koch-Klavsen acknowledges funding by "The Danish Council for Independent Research: Natural Sciences".

The service charges for this open access publication have been covered by a Research Centre of the Helmholtz Association.

Edited by: J. Middelburg

\section{References}

Aberle, N., Schulz, K. G., Stuhr, A., Ludwig, A., and Riebesell, U.: High tolerance of protozooplankton to ocean acidification in an Arctic coastal plankton community, Biogeosciences Discuss., 9, 13031-13051, doi:10.5194/bgd-9-13031-2012, 2012.

Armstrong, R. A., Lee, C., Hedges, J. I., Honjo, S., and Wakeham, S.: A new, mechanistic model for organic carbon fluxes in the ocean based on the quantitative association of POC with ballast minerals, Deep-Sea Res., 49, 219-236, 2001.

Barlow, R. G., Cummings, D. G., and Gibb, S. W.: Improved resolution of mono- and divinyl chlorophylls a and $\mathrm{b}$ and zeaxanthin and lutein in phytoplankton extracts using reverse phase $\mathrm{C}-8$ HPLC., Mar. Ecol.-Prog. Ser., 161, 303-307, 1997.

Bates, N. R., Mathis, J. T., and Cooper, L. W.: Ocean acidification and biologically induced seasonality of carbonate mineral saturation states in the Western Arctic Ocean, J. Geophys. Res., 114, C11007, doi:10.1029/2008JC004862, 2009.

Bellerby, R. G. J., Silyakova, A., Nondal, G., Slagstad, D., Czerny, J., de Lange, T., and Ludwig, A.: Marine carbonate system evolution during the EPOCA Arctic pelagic ecosystem experiment in the context of simulated Arctic ocean acidification, Biogeosciences Discuss., 9, 15541-15565, doi:10.5194/bgd-9-155412012, 2012.

Biswas, H., Cros, A., Yadav, K., Ramana, V. V., Prasud, V. R., Acharyya, T., and Babu, P. V.: The response of a natural phytoplankton community from the Godavari River Estuary to increasing $\mathrm{CO}_{2}$ concentrations during the pre-monsoon period, J. Exp. Mar. Biol. Ecol., 407, 284-293, 2011.

Broecker, W. S. and Peng, T.-H.: Tracers in the Sea, LamontDoherty Earth Obsercatory, Palisades, NY, 1982. 
Brussaard, C. P. D., Noordeloos, A. A. M., Witte, H., Collenteur, M. C. J., Schulz, K., Ludwig, A., and Riebesell, U.: Arctic microbial community dynamics influenced by elevated $\mathrm{CO}_{2}$ levels, Biogeosciences Discuss., 9, 12309-12341, doi:10.5194/bgd9-12309-2012, 2012

Clarke, K. R. and Gorley, R. N.: Primer v6: user manual/tutorial, PRIMER-E Ltd., Plymouth, p. 190, 2006.

Clarke, K. R. and Warwick, R. M.: Change in marine communities: an approach to statistical analysis and interpretations, PRIMERE Ltd., Plymouth, p. 144, 2001.

Clarke, K. R., Somerfield, P. J., Airoldi, L., and Warwick, R. M.: Exploring interactions by second-stage community analyses, J. Exp. Mar. Biol. Ecol., 338, 179-192, 2006.

Cottingham, K. L., Lennon, J. T., and Brown, B. L.: Knowing when to draw the line: designing more informative ecological experiments, Front. Ecol. Environ., 3, 145-152, 2005.

Cuvelier, M. L., Allen, A. E., Monier, A., McCrow, J. P., Messié, M., Tringe, S. G., Woyke, T., Welsh, R. M., Ishoey, T., Lee, J.H., Binder, B. J., DuPont, C. L., Latasa, M., Guigand, C., Buck, K. R., Hilton, J., Thiagarajan, M., Caler, E., Read, B., Lasken, R. S., Chavez, F. P., and Worden, A. Z.: Targeted metagenomics and ecology of globally important uncultured eukaryotic phytoplankton, P. Natl. Acad. Sci. USA, 107, 14679-14684, 2010.

Czerny, J., Schulz, K. G., Boxhammer, T., Bellerby, R. G. J., Büdenbender, J., Engel, A., Krug, S. A., Ludwig, A., Nachtigall, K., Nondal, G., Niehoff, B., Siljakova, A., and Riebesell, U.: Element budgets in an Arctic mesocosm $\mathrm{CO}_{2}$ perturbation study, Biogeosciences Discuss., 9, 11885-11924, doi:10.5194/bgd-911885-2012, 2012a.

Czerny, J., Schulz, K. G., Krug, S. A., Ludwig, A., and Riebesell, U.: Technical Note: On the determination of enclosed water volume in large flexible-wall mesocosms, Biogeosciences Discuss., 9, 13019-13030, doi:10.5194/bgd-9-13019-2012, 2012b.

de Kluijver, A., Soetaert, K., Schulz, K. G., Riebesell, U., Bellerby, R. G. J., and Middelburg, J. J.: Phytoplankton-bacteria coupling under elevated $\mathrm{CO}_{2}$ levels: a stable isotope labelling study, Biogeosciences, 7, 3783-3797, doi:10.5194/bg-7-3783-2010, 2010.

de Kluijver, A., Soetaert, K., Czerny, J., Schulz, K. G., Boxhammer, T., Riebesell, U., and Middelburg, J. J.: A ${ }^{13} \mathrm{C}$ labelling study on carbon fluxes in Arctic plankton communities under elevated $\mathrm{CO}_{2}$ levels, Biogeosciences Discuss., 9, 8571-8610, doi:10.5194/bgd-9-8571-2012, 2012.

Engel, A., Zondervan, I., Aerts, K., Beaufort, L., Benthien, A., Chou, L., Delille, B., Gattuso, J.-P., Harlay, J., Heemann, C., Hoffmann, L., Jacquet, S., Nejstgaard, J., Pizay, M. D., RochelleNewall, E., Schneider, U., Terbrueggen, A., and Riebesell, U.: Testing the direct effect of $\mathrm{CO}_{2}$ concentration on a bloom of the coccolithophorid Emiliania huxleyi in mesocosm experiments, Limnol. Oceanogr., 50, 493-507, 2005.

Engel, A., Schulz, K. G., Riebesell, U., Bellerby, R., Delille, B., and Schartau, M.: Effects of $\mathrm{CO}_{2}$ on particle size distribution and phytoplankton abundance during a mesocosm bloom experiment (PeECE II), Biogeosciences, 5, 509-521, doi:10.5194/bg-5-5092008, 2008.

Engel, A., Borchard, C., Piontek, J., Schulz, K., Riebesell, U., and Bellerby, $\mathrm{R}$.: $\mathrm{CO}_{2}$ increases ${ }^{14} \mathrm{C}$-primary production in an Arctic plankton community, Biogeosciences Discuss., 9, 10285-10330, doi:10.5194/bgd-9-10285-2012, 2012.
Feng, Y., Hare, C. E., Leblanc, K., Rose, J., Zhang, Y., DiTullio, G. R., Lee, P. A., Wilhelm, S. W., Rowe, J. M., Sun, J., Nemcek, N., Gueguen, C., Passow, U., Benner, I., Brown, C., and Hutchins, D. A.: Effects of increased $p \mathrm{CO}_{2}$ and temperature on the North Atlantic spring bloom. I. The phytoplankton community and biogeochemical response, Mar. Ecol. Progr. Ser., 388, 13-25, 2009.

Francois, R., Honjo, S., Krishfield, R., and Manganini, S.: Factors controlling the flux of organic carbon to the bathypelagic zone of the ocean, Global Biogeochem. Cy., 16, 1087 , doi:1010.1029/2001GB001722, 2002.

Gattuso, J.-P., Lee, K., Rost, B., and Schulz, K. G.: Approaches and tools to manipulate the carbonate chemistry, in: Guide to Best Practices in Ocean Acidification Research and Data Reporting, edited by: Riebesell, U., Fabry, V. J., and Gattuso, J.-P., http://www.epoca-project.eu/index.php/guide-to-best-practicesfor-ocean-acidification-research-and-data-reporting.html, 2010.

Giordano, M., Beardall, J., and Raven, J. A.: $\mathrm{CO}_{2}$ concentrating mechanisms in algae: mechanisms, environmental modulation, and evolution, Annu. Rev. Plant. Biol., 56, 99-131, 2005.

Halldal, P. and Halldal, K.: Phytoplankton, Chlorophyll, and Submarine Light Conditions in Kings Bay, Spitsbergen, July 1971, Norw. J. Bot., 20, 99-108, 1973.

Hansen, H. P. and Koroleff, F.: Determination of nutrients, in: Methods of Seawater Analysis, edited by: Grasshoff, K. K. K. and Ehrhardt, M., John Wiley, Hoboken, NJ, 159-229, 1999.

Hare, C. E., Leblanc, K., DiTullio, G. R., Kudel, R. M., Zhang, Y., Lee, P. A., Risman, S., and Hutchins, D. A.: Consequences of increased temperature and $\mathrm{CO}_{2}$ for phytoplankton community structure in the Bering Sea, Mar. Ecol. Progr. Ser., 352, 9-16, 2007.

Havenhand, J. Dupont, S. and Quinn, G. P.: Designing ocean acidification experiments to maximise inference, in: Guide to Best Practices in Ocean Acidification Research and Data Reporting, edited by: Riebesell, U., Fabry, V. J., and Gattuso, J.-P., http://www.epoca-project.eu/index.php/guide-to-best-practicesfor-ocean-acidification-research-and-data-reporting.html, 2010.

Holmes, R. M., Aminot, A., Kérgouel, R., Hooker, B. A., and Peterson, B. J.: A simple and precise method for measuring ammonium in marine and freshwater ecosystems, Can. J. Fish. Aquat. Sci., 56, 1801-1808, 1999.

Hop, H., Pearson, T., Hegseth, E. N., Kovacs, K. M., Wiencke, C., Kwasniewski, S., Eiane, K., Mehlum, F., Gulliksen, B., Wlodarska-Kowalczuk, M., Lydersen, C., Weslawski, J. M., Cochrane, S., Gabrielsen, G. W., Leakey, R. J. G., Lønne, O. J., Zajaczkowski, M., Falk-Petersen, S., Kendall, M., Wängberg, S.-A ., Bischof, K., Voronkov, A.Y., Kovaltchouk, N.A., Wiktor, J., Poltermann, M., diPrisco, G., Papucci, C., and Gerland, S.: The marine ecosystem of Kongsfjorden, Svalbard, Polar Res., 21, 157-208, 2002.

Hop, H., Falk-Peterson, S., Svendsen, S., Kwasniewski, V., Pavlov, V., Pavlova, O., and Søreide, J. E.: Physical and biological characteristics of the pelagic system across Fram Strait to Kongsfjorden, Progr. Oceanogr., 71, 182-231, 2006.

Hoppenrath, M., Elbrächter, M., and Drebes, G. (Eds.): Marine phytoplankton: selected microphytoplankton species from the North Sea around Helgoland and Sylt, Schweizerbart Science Publishers, Stuttgart, 2009.

Iglesias-Rodríguez, M. D., Nimer, N. A., and Merret, M. J.: Carbon dioxide-concentrating mechanism and the development of 
extracellular carbonic anhydrase in the marine picoeukaryote $\mathrm{Mi}$ cromonas pusilla, New Phytol., 140, 685-690, 1998.

Iversen, K. R. and Seuthe, L.: Seasonal microbial processes in a high-latitude fjord (Kongsfjorden, Svalbard): I. Heterotrophic bacteria, picoplankton and nanofagellates, Polar Biol., 34, 731749, 2011

Keck, A., Wiktor, J., Hapter, R., and Nilsen, R.: Phytoplankton assemblages related to physical gradients in an arctic, glacier-fed fjord in summer, ICES J. Mar. Sci., 56, Suppl., 203-214, 1999.

Kerouel, R. and Aminot, A.: Fluorometric determination of ammonia in sea and estuarine waters by direct segmented flow analysis, Mar. Chem., 57, 265-275, 1997.

Kim, J.-M., Lee, K., Shin, K., Kang, J.-H., Lee, H.-W., Kim, M., Jang, P.-G., and Jang, M.-C.: The effect of seawater $\mathrm{CO}_{2}$ concentration on growth of a natural phytoplankton assemblage in a controlled mesocosm experiment, Limnol. Oceanogr., 5, 16291636, 2006.

Kim, J.-M., Lee, K., Shin, K., Yang, E. J., and Engel, A.: Shifts in biogenic carbon flow from particulate to dissolved forms under high carbon dioxide and warm ocean conditions, Geophys. Res. Lett., 38, L08612, doi:10.1029/2011GL047346, 2011.

Klaas, C. and Archer, D. E.: Association of sinking organic matter with various types of mineral ballast in the deep sea: implications for the rain ratio, Global Biogeochem. Cy., 16, 1116, doi:1110.1029/2001GB001765, 2002.

Kraberg, A., Baumann, M., and Dürselen, C.-D.: Coastal Phytoplankton: Photo Guide for Northern European Seas, Pfeil, München, 2010.

Kroeker, K. J., Kordas, R. L., Crim, R. N., and Singh, G. G.: Metaanalysis reveals negative yet variable effects of ocean acidification on marine organisms, Ecol. Lett., 13, 1419-1343, 2010.

Laws, E. A.: Photosynthetic quotients, new producion and net community production in the open ocean, Deep-Sea Res., 38, 143167, 1991.

Lui, H., Probert, I., Uitz, J., Claustre, H., Aris-Brosou, S., Frada, M., Not, F., and de Vargas, C.: Extreme diversity in noncalcifying haptophytes explains a major pigment paradox in open oceans, $\mathrm{P}$. Natl. Acad. Sci. USA, 106, 10809-12808, 2009.

Mackey, M. D., Mackey, D. J., Higgins, H. W., and Wright, S. W.: CHEMTAX - a program for estimating class abundances from chemical markers: application to HPLC measurements of phytoplankton, Mar. Ecol.-Prog. Ser., 144, 265-283, 1996.

Marinov, I., Doney, S. C., and Lima, I. D.: Response of ocean phytoplankton community structure to climate change over the $21 \mathrm{st}$ century: partitioning the effects of nutrients, temperature and light, Biogeosciences, 7, 3941-3959, doi:10.5194/bg-7-39412010, 2010.

Meakin, N. G. and Wyman, M.: Rapid shifts in picoeukaryote community structure in response to ocean acidification, ISME J., 5, 1397-1405, 2011.

Mehrbach, C., Culberson, C. H., Hawley, J. E., and Pytkowicz, R. M.: Measurements of the apparent dissociation constants of carbonic acid in seawater at atmospheric pressure, Limnol. Oceanogr., 18, 897-907, 1973.

Menden-Deuer, S. and Lessard, E. L.: Carbon to volume relationships for dinoflagellates, diatoms, and other protist plankton, Limnol. Oceanogr., 45, 569-579, 2000.

Montagnes, D. J. S., Berges, A., Harrison, P. J., and Taylor, F. J. R.: Estimating carbon, nitrogen, protein, and chlorophyll $a$ from volume in marine phytoplankton, Limnol. Oceanogr., 39, 1044-1060, 1994

Newbold, L. K., Oliver, A. E., Booth, T., Tiwari, B., DeSantis, T., Maguire, M., Andersen, G., van der Gast, C., and Whiteley, A. S.: The response of marine picoplankton to ocean acidification, Environ. Microbiol., 14, 2293-2307, doi:10.1111/j.14622920.2012.02762.x, 2012.

Niehoff, B., Knüppel, N., Daase, M., Czerny, J., and Boxhammer, T.: Mesozooplankton community development at elevated $\mathrm{CO}_{2}$ concentrations: results from a mesocosm experiment in an Arctic fjord, Biogeosciences Discuss., 9, 11479-11515, doi:10.5194/bgd-9-11479-2012, 2012.

Olenina, I., Hajdu, S., Edler, L., Andersson, A., Wasmund, N., Busch, S., Göbel, J., Gromisz, S., Huseby, S., Huttunen, M., Jaanus, A., Kokkonen, P., Ledaine, I., and Niemkiewicz: Biovolumes and size-classes of phytoplankton in the Baltic Sea, HELCOM Balt. Sea Environ. Proc., 106, 1-144, 2006.

Passow, U.: Switching perspectives: do mineral fluxes determine particulate organic carbon fluxes or vice versa?, Geochem. Geophy. Geosy., 5, ISSN 1525-2027, doi:10.1029/2003GC000670, 2004.

Paulino, A. I., Egge, J. K., and Larsen, A.: Effects of increased atmospheric $\mathrm{CO}_{2}$ on small and intermediate sized osmotrophs during a nutrient induced phytoplankton bloom, Biogeosciences, 5, 739-748, doi:10.5194/bg-5-739-2008, 2008.

Redfield, A. C., Ketchum, B. H., and Richards, F. A.: The influence of organisms on the composition of seawater, in: The Sea, 2nd Edn., edited by: Hill, M. N., Wiley, New York, 26-77, 1963.

Reinfelder, J. R.: Carbon Concentrating Mechanisms in Eukaryotic Marine Phytoplankton, Annu. Rev. Mar. Sci., 3, 291-315, 2010.

Riebesell, U., Wolf-Gladrow, D. A., and Smetacek, V.: Carbon dioxide limitation of marine phytoplankton, Nature, 361, 249-251, 1993.

Riebesell, U., Bellerby, R. G. J., Grossart, H.-P., and Thingstad, F.: Mesocosm $\mathrm{CO}_{2}$ perturbation studies: from organism to community level, Biogeosciences, 5, 1157-1164, doi:10.5194/bg-51157-2008, 2008.

Riebesell, U., Körtzinger, A., and Oschlies, A.: Sensetivities of marine carbon fluxes to climate change, P. Natl. Acad. Sci. USA, 106, 20602-20609, 2009.

Riebesell, U., Czerny, J., von Bröckel, K., Boxhammer, T., Büdenbender, J., Deckelnick, M., Fischer, M., Hoffmann, D., Krug, S. A., Lentz, U., Ludwig, A., Muche, R., and Schulz, K. G.: Technical Note: A mobile sea-going mesocosm system - new opportunities for ocean change research, Biogeosciences Discuss., 9, 12985-13017, doi:10.5194/bgd-9-12985-2012, 2012.

Sarmiento, J. L., Slater, R., Barber, R., Bopp, L., Doney, S. C., Hirst, A. C., Kleypas, J., Matear, R., Mikolajewicz, U., Monfreay, P., Soldatov, V., Spall, S. A., and Stouffer, R.: Response of ocean ecosystems to climate warming, Global Biogeochem. Cy., 18, GB3003, doi:10.1029/2003GB002134, 2004.

Schulz, K. G. and Riebesell, U.: Diurnal changes in seawater carbonate chemistry speciation at increasing atmospheric carbon dioxide, Mar. Biol.,doi:10.1007/s00227-012-1965-y, 2012.

Schulz, K. G., Riebesell, U., Bellerby, R. G. J., Biswas, H., Meyerhöfer, M., Müller, M. N., Egge, J. K., Nejstgaard, J. C., Neill, C., Wohlers, J., and Zöllner, E.: Build-up and decline of organic matter during PeECE III, Biogeosciences, 5, 707-718, doi:10.5194/bg-5-707-2008, 2008. 
Schulz, K. G., Barcelos e Ramos, J., Zeebe, R. E., and Riebesell, $\mathrm{U}$.: $\mathrm{CO}_{2}$ perturbation experiments: similarities and differences between dissolved inorganic carbon and total alkalinity manipulations, Biogeosciences, 6, 2145-2153, doi:10.5194/bg-6-21452009, 2009.

Sharp, J. H.: Improved analysis for 'particulate' organic carbon and nitrogen from seawater, Limnol. Oceanogr., 19, 984-989, 1974.

Silyakova, A., Bellerby, R. G. J., Czerny, J., Schulz, K. G., Nondal, G., Tanaka, T., Engel, A., De Lange, T., and Riebesell, U.: Net community production and stoichiometry of nutrient consumption in a pelagic ecosystem of a northern high latitude fjord: mesocosm $\mathrm{CO}_{2}$ perturbation study, Biogeosciences Discuss., 9, 11705-11737, doi:10.5194/bgd-9-11705-2012, 2012.

Steinacher, M., Joos, F., Frölicher, T. L., Plattner, G.-K., and Doney, S. C.: Imminent ocean acidification in the Arctic projected with the NCAR global coupled carbon cycle-climate model, Biogeosciences, 6, 515-533, doi:10.5194/bg-6-515-2009, 2009.

Taucher, J., Schulz, K. G., Dittmar, T., Sommer, U., Oschlies, A., and Riebesell, U.: Enhanced carbon overconsumption in response to increasing temperatures during a mesocosm experiment, Biogeosciences, 9, 3531-3545, doi:10.5194/bg-9-35312012, 2012.

Tomas, C. R. (Ed.): Identifying marine phytoplankton, Academic Press, San Diego, 1997.

Tortell, P. D., DiTullio, G. R., Sigman, D. M., and Morel, F. M. M.: $\mathrm{CO}_{2}$ effects on taxonomic composition and nutrient utilization in an Equatorial Pacific phytoplankton assemblage, Mar. Ecol. Progr. Ser., 23, 37-43, 2002.

Tortell, P. D., Payne, C. D., Li, Y., Trimborn, S., Rost, B., Smith, W. O., Riesselman, C., Dunbar, R. B., Sedwick, P., and DiTullio, G. R.: $\mathrm{CO}_{2}$ sensitivity of Southern Ocean phytoplankton, Geophys. Res. Lett., 35, L04605, doi:10.1029/2007GL032583, 2008.

Uitz, J., Claustre, H., Gentili, B., and Stramski, D.: Phytoplankton class-specific primary production in the world's oceans: Seasonal and interannual variability from satellite observations, Global Biogeochem. Cy., 24, GB3016, doi:10.1029/2009GB003680, 2010 . von Quillfeldt, C. H.: Ice algae and phytoplankton in north Norwegian and Arctic waters: species composition, succession and distribution, PhD, University of Troms $\varnothing, 1996$.

Welschmeyer, N. A.: Fluorometric analysis of chlorophyll $a$ in the presence of chlorophyll $b$ and pheopigments, Limnol. Oceanogr., 39, 1985-1992, 1994

Wohlers, J., Engel, A., Zöllner, E., Breithaupt, P., Jürgens, K., Hoppe, H.-G., Sommer, U., and Riebesell, U.: Changes in biogenic carbon flow in response to sea surface warming, P. Natl Acad. Sci. USA, 106, 7067-7072, 2009.

Worden, A. Z. Lee, J. H., Mock, T., Rouzé, P., Simmons, M. P., Aerts, A. L., Allen, A. E., Cuvelier, M. L., Derelle, E., Everett, M. V., Foulon, E., Grimwood, J., Gundlach, H., Henrissat, B., Napoli, C., McDonald, S. M., Parker, M. S., Rombauts, S., Salamov, A., Von Dassow, P., Badger, J. H., Coutinho, P. M., Demir, E., Dubchak, I., Gentemann, C., Eikrem, W., Gready, J. E., John, U., Lanier, W., Lindquist, E. A., Lucas, S., Mayer, K. F., Moreau, H., Not, F., Otillar, R., Panaud, O., Pangilinan, J., Paulsen, I., Piegu, B., Poliakov, A., Robbens, S., Schmutz, J., Toulza, E., Wyss, T., Zelensky, A., Zhou, K., Armbrust, E. V., Bhattacharya, D., Goodenough, U. W., Van de Peer, Y., and Grigoriev, I. V.: Green evolution and dynamic adaptations revealed by genomes of the marine picoeukaryotes Micromonas, Science, 324, 268-272, 2009.

Yamamoto-Kawai, M., McLaughlin, F. A., Carmack, E. C., Nishino, S., and Shimada, K.: Aragonite undersaturation in the Arctic ocean:effects of ocean acidification and sea ice melt, Science, 326, 1098-1100, 2009. 